\title{
A study of the association between self-awareness, personal \& social competence with the emotional intelligence of software professional in IT industry in India.
}

\author{
${ }^{1}$ Sashakt Singh, ${ }^{2}$ Prof. IleyasRizvi, \\ ${ }^{1}$ Research scholar, Kalinga University \&Managing Director,Aryakul Group of colleges. \\ ${ }^{2}$ Director,Management \& Research Institute.
}

\begin{abstract}
The aim of the present study has been to investigate the association between self-awareness, personal \& social competence with the emotional intelligence of software professional in IT industry in India. The study was conducted in IT industry in India. A structured questionnaire was developed by the researcher based on emotional intelligence competencies as given by Daniel Goleman $(1995,1998)$ and other researchers and was applied in IT service industry. A sample of 500 software professionals' primary data was collected through convenience sampling technique and statistical tools like frequency analysis, crosstabulation analysis and chi square analysis were used for data analysis. The statistical data were computed by SPSS 21.0 for Windows. The results of the analysis found statistically significant and positive correlations between two variables of study; this means that high level of self-awareness, personal and social competence of software professionals was associated with the emotional intelligence of software professionals. The primary focus of software professionals is on the technical knowledge and expertise. But the previous studies, as well as the present research proved the importance of emotional intelligence for the software professionals in order to improve their effectiveness and efficiency in an organisation as well as to serve the clients. The more the level of emotional intelligence, the higher will be the performance of software professionals.
\end{abstract}

Keywords:Emotional Intelligence, Personal Competence, Social Competence, Software Professionals \& Indian IT industry.

\section{Introduction}

The importance of emotional intelligence for the employees in any organisation cannot be ignored. Organisation are training and developing their employees to improve their performance as well as service delivery process with clients. In the service industry, EI is of great importance, especially in IT industry where software professionals have to directly deal with corporate clients. In service delivery process, knowledge and technical skills of the software professionals play a major role but their behavioural competence cannot be ignored. Emotional Intelligence is considered as a group of several positive emotions such as self-awareness, emotional management skills to balance emotion and reasoning to enhance performance and better emotional adjustment at the workplace. Many research studies had been conducted to find out the association of EI with its association and correlation to leadership effectiveness. (Goleman et. al, 2002) Emotional labour and an individual employee's performance were studied by Douglass et. al, (2004), and the result showed the positive relationship between the two.Adeyemo, (2007), did a research and found the positive correlation between job satisfaction and organisational commitment.EI was also found to be positively related to leadership performance (Cook, 2006) and profitability and financial success of any company or organisation (Bradberry and Greaves, 2003). Further, findings of the research studies conducted by Cherniss, (2000) and Feist and Barron, (1996), showed that Emotional Intelligence based competencies are far better predictors of an individual's performance as well as his flexibility and adjustment at the workplace.As these competencies symbolise the level of individuals' work performance and degree of adaptability and adjustment a person will have to his environment.

\subsection{Statement of the Research Problem}

This study is intended to find the association between self-awareness, personal and social competence of software professionals in IT industry in India. The present study is an attempt to uncover some of the competencies that distinguish outstanding software professional from average software professional. The study is aimed at acquiring preliminary information on the emotional intelligence profiles of practicing software professionals. There is a lack of reliable published information on this topic.

\subsection{Justification \& Significance of the Research}

The present research conducted a preliminary and exploratory study examining the influence of self-awareness, personal and social competence on the emotional intelligence of software professionals. A key objective was to gain an understanding of how important these attributes are to software professionals in performance. This 
Topic: A study of the association between self-awareness, personal \& social competence with the

knowledge could be contributory in the development of contemporary software professionals and mentoring of future software professional.

\subsection{Research objectives and Research Hypotheses}

Research Objective-1: To study the association between the factors of self-awareness and Emotional Intelligence of software professionals in I.T. industry in India.

Alternate Hypothesis (H1)- 1: There is an association between the factors of self-awareness and Emotional Intelligence of software professionals in I.T. industry in India.

Null Hypothesis (H0)- 1: There is no association between the factors of self-awareness and Emotional Intelligence of software professionals in I.T. industry in India.

Research objectives-2: To study the association between the factors of Personal competence and Emotional Intelligence of software professionals in I.T. industry in India.

Alternate Hypothesis (H1)- 2: There is an association between the factors of Personal competence and Emotional Intelligence of software professionals in I.T. industry in India.

Null Hypothesis (H0)- 2: There is no association between the factors of Personal competence and Emotional Intelligence of software professionals in I.T. industry in India.

Research objectives-3: To study the association between the factors of Social competence and Emotional Intelligence of software professionals in I.T. industry in India.

Alternate Hypothesis (H1)- 3: There is an association between the factors of Social competence and Emotional Intelligence of software professionals in I.T. industry in India.

Null Hypothesis (H0)- 3: There is no association between the factors of Social competence and Emotional Intelligence of software professionals in I.T. industry in India.

\section{Review Of Related Literature}

Travis Bradberry, (2014)in his article on Emotional Intelligence - EQ, published by Forbes describes selfawareness, personal and social competence as follows-

- Personal competence is made up of your self-awareness and self-management skills, which focus more on you individually than on your interactions with other people. Personal competence is your ability to stay aware of your emotions and manage your behaviour and tendencies.

- Self-Awareness is your ability to accurately perceive your emotions and stay aware of them as they happen.

- Self-Management is your ability to use awareness of your emotions to stay flexible and positively direct your behavior.

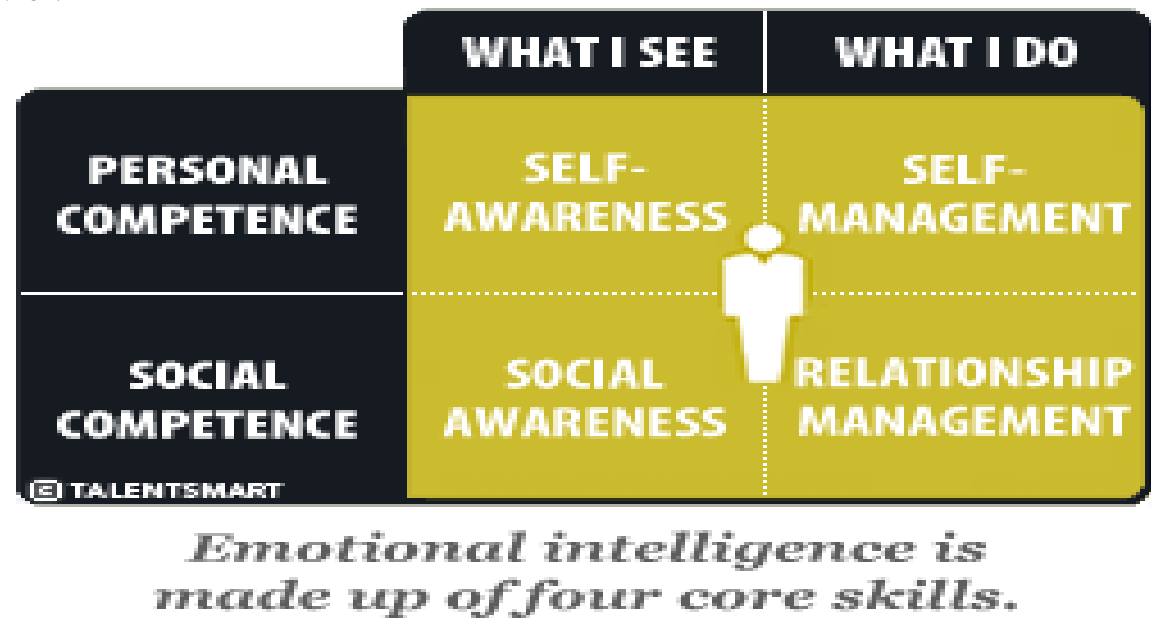

Social competence is made up of your social awareness and relationship management skills; social competence is your ability to understand other people's moods, behavior, and motives in order to improve the quality of your relationships.

- Social Awareness is your ability to accurately pick up on emotions in other people and understand what is really going on.

- Relationship Management is your ability to use awareness of your emotions and the others' emotions to manage interactions successfully.

(Source: www.forbes.com/sites/travisbradberry/2014/01/09/emotionalintelligence/)

According to Mayer \&Ciarrochi, (2006), generally, people can solve technical problems far easier than human 
problems they face in home as well as in professional life.

Wong, Kenneth, (2002) andAbraham,J.(2004), in their respective researches concluded that in order to realize the full range of capabilities and core competencies of human resources, strategic human resource managers should not focus narrowly on task performance while designing employee performance management systems.

They should emphasize-

- The employee development rather than control, and should

- Consider employees' actual and potential contributions in the supporting performance

- Employees' emotions, and

- Employees' ethics.

Wilkinson, Kleitman, Stankov (2002), concluded that managers use fear, pride and other emotions to both treat and motivate their subordinates.

Dulewicz\& Higgs, (1999) and various other researches have shown that $36 \%$ of variance in individual success in organizational setting is explained through emotional intelligence.

Allspach, \&Breining, K. (2005), found that the EI-Performance link also seems logical because increasingly, the employers are considering the applicants' EI during the recruitment and selection processes.

Barchard, (2004), concluded that in large part, customers (clients) judge the quality of their experience (quality of IT services delivered by software professionals) by how much of the variability they introduce is accommodated, so the choice to reduce or rule out the variability is eliminated.So, the present research focused on the competence of software professionals. The factors of behavioural competence that were taken into account were self-awareness, personal and social competence. It is hypothesised that all these competencies make software professional emotionally intelligent, hence it will also lead to improved individual as well as organisational performance.

\section{Research Design And Methodology}

A research design is considered to be a plan or blueprint of how the researcher intends conducting the research. The research design basically focuses on the end product: What kind of study is being planned and what kind of result is aimed at? Research methodology focuses on the research process and the kind of tools and procedures to be used.

\subsection{Methodology}

To study the emotional intelligence of software professionals of I.T. industry, an Emotional Intelligence test in the form of the questionnaire was used which was based on nine components namely: personal competence, social competence, optimism, pessimism, self-awareness, empathy and resilience. A structured questionnaire, having multiple choices, dichotomous, objective questions (5 point LIKERT scale) was used. The Sample Unit was a software professional working in the I.T. industry in India and the Sample Size for the proposed research will be $\mathbf{5 0 0}$ which were taken from all over India, the Universe of the research to know the emotional intelligence of the software professionals. The researcher used Convenient Sampling Technique to collect primary data with the help of Questionnaires as well as Schedules. Questionnaires were sent to the software professionals through emails also.

\section{Data Analysis \& Interpretationand Findings \\ 4.1. Demographic Profile of the Software Professionals working in IT Industry in India The main demographic information of respondents is summarized below:}

In case of the software professionals in IT industry in India, the majority of thesoftware professionals surveyedwere males (70.6\%) and females were (29.4\%). We can see that majority $64.2 \%$ software professionals belong to 20-30 age group. And $66.8 \%$ respondents were married and $33.2 \%$ respondents were unmarried. $29.8 \%$ respondents were diploma holders, $22.8 \%$ respondents were MCA / M.Tech, $22.4 \%$ respondents were B.Tech. and $21.8 \%$ respondents have other technical qualification. Designation of $41.0 \%$ respondents was junior level, designation of $50.8 \%$ respondents was middle level \& designation of $8.2 \%$ respondents was senior level.

4.2. CHI Square Analysis:Analysis of the Association between Emotional Intelligence and Self Awareness

4.2.1 Analysis: Self Awareness: Analysis of the relationship between emotional intelligence andI am conscious of my needs and wants in life of the software professional in India. 
Topic: A study of the association between self-awareness, personal \& social competence with the

H0: The two factors are independent.

H1: The two factors are not independent (associated).

Tool Used: Chi Square Test (Analyze $\rightarrow$ Descriptive Statistics $\rightarrow$ Crosstabs)

Table 4.1 Chi-Square Tests

\begin{tabular}{|l|l|l|l|}
\hline Chi-Square Tests & Value & df & Asymp. Sig. (2-sided) \\
\hline & $275.903^{\text {a }}$ & 16 & .000 \\
\hline Pearson Chi-Square & 59.464 & 16 & .000 \\
\hline Likelihood Ratio & 7.436 & 1 & .006 \\
\hline Linear-by-Linear Association & 500 & & \\
\hline N of Valid Cases & T. The minimum expected count is .04. \\
\hline
\end{tabular}

Table 4.2Symmetric Measures

\begin{tabular}{|c|c|c|c|}
\hline \multicolumn{4}{|l|}{ Symmetric Measures } \\
\hline & & Value & Approx. Sig. \\
\hline Nominal by Nominal & Contingency Coefficient & .596 & .000 \\
\hline $\mathbf{N}$ of Valid Cases & & 500 & \\
\hline
\end{tabular}

Interpretation: From the table we find out that asymptotic significance for Pearson Chi Square comes out to be 0.000 (less than 0.05 ) so we reject null hypothesis at $5 \%$ level of significance. Hence it can be concluded that two variables are associated.

Table 4.3Crosstab: I am conscious of my needs and wants in life.

\begin{tabular}{|c|c|c|c|c|c|c|c|c|}
\hline \multicolumn{9}{|l|}{ Crosstab } \\
\hline \multirow{8}{*}{$\begin{array}{l}\text { I am } \\
\text { emotionally } \\
\text { intelligent. }\end{array}$} & $\begin{array}{l}\text { Strongly } \\
\text { agree }\end{array}$ & Count & 94 & 36 & 0 & 4 & 0 & 134 \\
\hline & \multirow{2}{*}{ Agree } & Count & 122 & 58 & 8 & 10 & 0 & 198 \\
\hline & & $\%$ of Total & $24.4 \%$ & $11.6 \%$ & $1.6 \%$ & $2.0 \%$ & $0.0 \%$ & $39.6 \%$ \\
\hline & Neutral & Count & 102 & 30 & 7 & 3 & 0 & 142 \\
\hline & \multirow{2}{*}{ Disagree } & Count & 7 & 10 & 3 & 0 & 0 & 20 \\
\hline & & $\%$ of Total & $1.4 \%$ & $2.0 \%$ & $0.6 \%$ & $0.0 \%$ & $0.0 \%$ & $4.0 \%$ \\
\hline & \multirow{2}{*}{$\begin{array}{l}\text { Strongly } \\
\text { disagree }\end{array}$} & Count & 3 & 0 & 0 & 0 & 3 & 6 \\
\hline & & $\%$ of Total & $0.6 \%$ & $0.0 \%$ & $0.0 \%$ & $0.0 \%$ & $0.6 \%$ & $1.2 \%$ \\
\hline \multirow{2}{*}{\multicolumn{2}{|c|}{ Total }} & Count & 328 & 134 & 18 & 17 & 3 & 500 \\
\hline & & $\%$ of Total & $65.6 \%$ & $26.8 \%$ & $3.6 \%$ & $3.4 \%$ & $0.6 \%$ & $100.0 \%$ \\
\hline
\end{tabular}

Interpretation: from the above crosstab, it can said that out of total 500 respondents (Software Professionals), $65.6 \%$ respondents strongly agreed, $26.8 \%$ respondents agreed, $3.6 \%$ respondents were neutral, $3.4 \%$ respondents disagreed and $0.6 \%$ respondents strongly disagreed that ' $I$ am conscious of my needs and wants in life.'

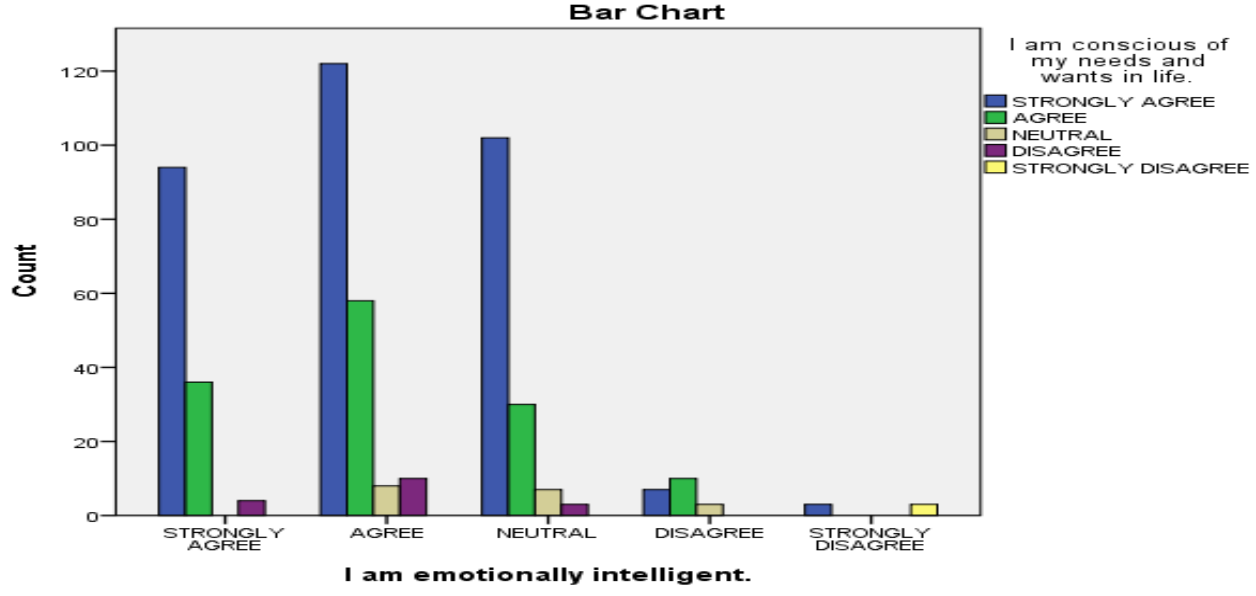

4.2.2 Analysis: Analysis of the relationship between emotional intelligence and I have a clear understanding about my own strengths and weakness. 
H0: The two factors are independent.

H1: The two factors are not independent (associated).

Tool Used: Chi Square Test (Analyze $\rightarrow$ Descriptive Statistics $\rightarrow$ Crosstabs)

Table 4.4Chi-Square Tests

\begin{tabular}{|l|l|l|l|}
\hline Chi-Square Tests & Value & df & Asymp. Sig. (2-sided) \\
\hline & $275.903^{\mathrm{a}}$ & 16 & .000 \\
\hline Pearson Chi-Square & 59.464 & 16 & .000 \\
\hline Likelihood Ratio & 7.436 & 1 & .006 \\
\hline Linear-by-Linear Association & 500 & & \\
\hline N of Valid Cases & 5. The minimum expected count is .04. \\
\hline a. 14 cells (56.0\%) have expected count less than \\
\hline
\end{tabular}

Table 4.5.Symmetric Measures

\begin{tabular}{|c|c|c|c|}
\hline \multicolumn{4}{|l|}{ Symmetric Measures } \\
\hline & & Value & Approx. Sig. \\
\hline Nominal by Nominal & Contingency Coefficient & .596 & .000 \\
\hline $\mathrm{N}$ of Valid Cases & & 500 & \\
\hline
\end{tabular}

Interpretation: From the table we find out that asymptotic significance for Pearson Chi Square comes out to be 0.000 (less than 0.05 ) so we reject null hypothesis at $5 \%$ level of significance. Hence it can be concluded that two variables are associated.

Table 4.6Crosstab: I have a clear understanding about my own strengths and weakness.

\begin{tabular}{|c|c|c|c|c|c|c|c|c|}
\hline \multicolumn{9}{|l|}{ Crosstab } \\
\hline & & & \multicolumn{5}{|c|}{ I have a clear understanding about my own strengths and weakness. } & \multirow[t]{2}{*}{ Total } \\
\hline & & & Strongly Agree & Agree & Neutral & Disagree & Strongly disagree & \\
\hline \multirow{10}{*}{$\begin{array}{l}\text { I am } \\
\text { emotionally } \\
\text { intelligent. }\end{array}$} & \multirow{2}{*}{$\begin{array}{l}\text { Strongly } \\
\text { agree }\end{array}$} & Count & 98 & 24 & 8 & 0 & 4 & 134 \\
\hline & & $\%$ of Total & $19.6 \%$ & $4.8 \%$ & $1.6 \%$ & $0.0 \%$ & $0.8 \%$ & $26.8 \%$ \\
\hline & \multirow{2}{*}{ Agree } & Count & 129 & 66 & 3 & 0 & 0 & 198 \\
\hline & & $\%$ of Total & $25.8 \%$ & $13.2 \%$ & $0.6 \%$ & $0.0 \%$ & $0.0 \%$ & $39.6 \%$ \\
\hline & \multirow{2}{*}{ Neutral } & Count & 110 & 29 & 0 & 3 & 0 & 142 \\
\hline & & $\%$ of Total & $22.0 \%$ & $5.8 \%$ & $0.0 \%$ & $0.6 \%$ & $0.0 \%$ & $28.4 \%$ \\
\hline & \multirow{2}{*}{ Disagree } & Count & 7 & 10 & 0 & 3 & 0 & 20 \\
\hline & & $\%$ of Total & $1.4 \%$ & $2.0 \%$ & $0.0 \%$ & $0.6 \%$ & $0.0 \%$ & $4.0 \%$ \\
\hline & \multirow{2}{*}{$\begin{array}{l}\text { Strongly } \\
\text { disagree }\end{array}$} & Count & 3 & 0 & 3 & 0 & 0 & 6 \\
\hline & & $\%$ of Total & $0.6 \%$ & $0.0 \%$ & $0.6 \%$ & $0.0 \%$ & $0.0 \%$ & $1.2 \%$ \\
\hline \multirow{2}{*}{\multicolumn{2}{|c|}{ Total }} & Count & 347 & 129 & 14 & 6 & \begin{tabular}{|l|}
4 \\
\end{tabular} & 500 \\
\hline & & $\%$ of Total & $69.4 \%$ & $25.8 \%$ & $2.8 \%$ & $1.2 \%$ & $0.8 \%$ & $100.0 \%$ \\
\hline
\end{tabular}

Interpretation: from the above crosstab, it can said that out of total 500 respondents (Software Professionals), $69.4 \%$ respondents strongly agreed, $25.8 \%$ respondents agreed, $2.8 \%$ respondents were neutral, $1.2 \%$ respondents disagreed and $0.8 \%$ respondents strongly disagreed that 'Ihave a clear understanding about my own strengths and weakness.'

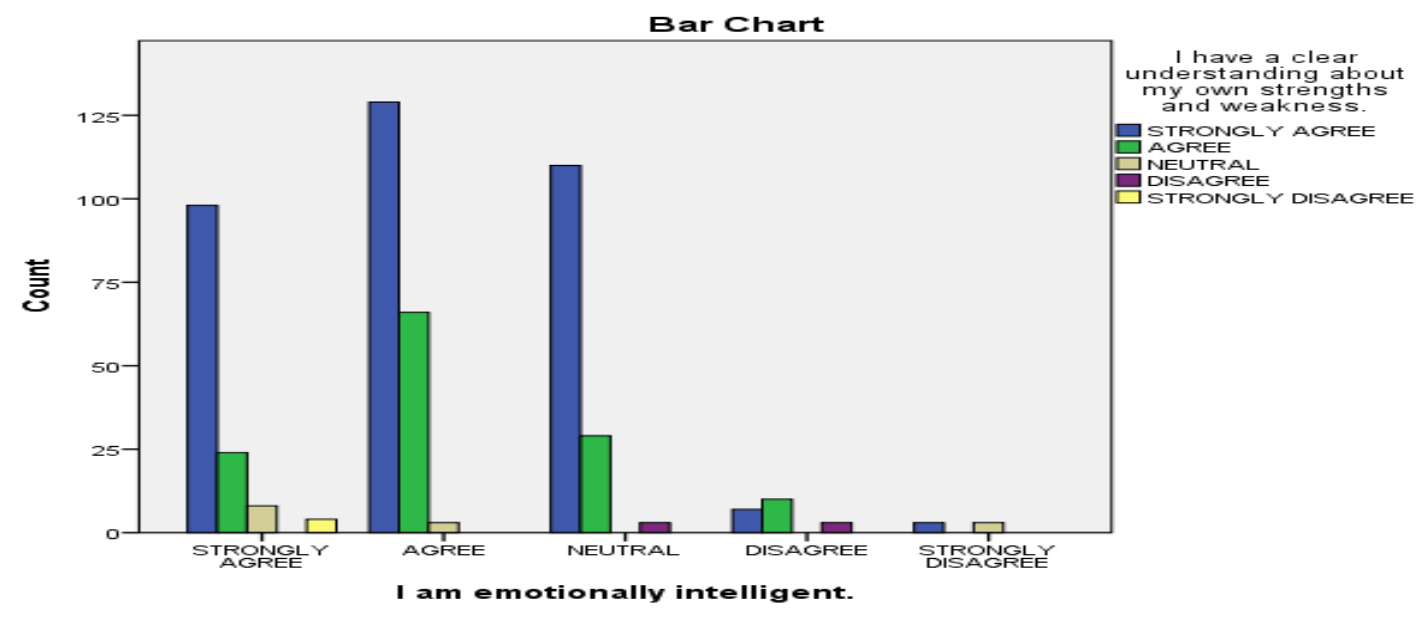


Topic: A study of the association between self-awareness, personal \& social competence with the

4.2.3 Analysis:Analysis of the relationship between emotional intelligenceand I am now aware of what I think and feel and how $I$ act in a situation.

H0: The two factors are independent.

H1: The two factors are not independent (associated).

Tool Used: Chi Square Test (Analyze $\rightarrow$ Descriptive Statistics $\rightarrow$ Crosstabs)

Table 4.7Chi-Square Tests

\begin{tabular}{|c|c|c|c|}
\hline \multicolumn{4}{|l|}{ Chi-Square Tests } \\
\hline & Value & df & Asymp. Sig. (2-sided) \\
\hline Pearson Chi-Square & $127.078^{\mathrm{a}}$ & 16 & .000 \\
\hline Likelihood Ratio & 77.389 & 16 & .000 \\
\hline Linear-by-Linear Association & .884 & 1 & .347 \\
\hline $\mathrm{N}$ of Valid Cases & 500 & & \\
\hline
\end{tabular}

Table 4.8Symmetric Measures

\begin{tabular}{|c|c|c|c|}
\hline \multicolumn{4}{|l|}{ Symmetric Measures } \\
\hline & & Value & Approx. Sig. \\
\hline Nominal by Nominal & Contingency Coefficient & .450 & .000 \\
\hline \multicolumn{2}{|l|}{$\mathrm{N}$ of Valid Cases } & 500 & \\
\hline
\end{tabular}

Interpretation: From the table we find out that asymptotic significance for Pearson Chi Square comes out to be 0.000 (less than 0.05 ) so we reject null hypothesis at $5 \%$ level of significance. Hence it can be concluded that two variables are associated.

Table 4.9Crosstab:I am now aware of what I think and feel and how I act in a situation.

\begin{tabular}{|c|c|c|c|c|c|c|c|c|}
\hline \multicolumn{9}{|l|}{ Crosstab } \\
\hline & & & \multicolumn{5}{|c|}{ I am now aware of what I think and feel and how I act in a situation. } & \multirow[t]{2}{*}{ Total } \\
\hline & & & Strongly agree & Agree & Neutral & Disagree & Strongly disagree & \\
\hline \multirow{10}{*}{$\begin{array}{l}\text { I am } \\
\text { emotionally } \\
\text { intelligent. }\end{array}$} & \multirow{2}{*}{$\begin{array}{l}\text { Strongly } \\
\text { agree }\end{array}$} & Count & 70 & 42 & 19 & 0 & 3 & 134 \\
\hline & & $\%$ of Total & $14.0 \%$ & $8.4 \%$ & $3.8 \%$ & $0.0 \%$ & $0.6 \%$ & $26.8 \%$ \\
\hline & \multirow{2}{*}{ Agree } & Count & 104 & 61 & 21 & 9 & 3 & 198 \\
\hline & & $\%$ of Total & $20.8 \%$ & $12.2 \%$ & $4.2 \%$ & $1.8 \%$ & $0.6 \%$ & $39.6 \%$ \\
\hline & \multirow{2}{*}{ Neutral } & Count & 61 & 41 & 22 & 9 & 9 & 142 \\
\hline & & $\%$ of Total & $12.2 \%$ & $8.2 \%$ & $4.4 \%$ & $1.8 \%$ & $1.8 \%$ & $28.4 \%$ \\
\hline & \multirow{2}{*}{ Disagree } & Count & 7 & 7 & 3 & 3 & 0 & 20 \\
\hline & & $\%$ of Total & $1.4 \%$ & $1.4 \%$ & $0.6 \%$ & $0.6 \%$ & $0.0 \%$ & $4.0 \%$ \\
\hline & \multirow{2}{*}{$\begin{array}{l}\text { Strongly } \\
\text { disagree }\end{array}$} & Count & 0 & 0 & 3 & 3 & 0 & 6 \\
\hline & & $\%$ of Total & $0.0 \%$ & $0.0 \%$ & $0.6 \%$ & $0.6 \%$ & $0.0 \%$ & $1.2 \%$ \\
\hline \multirow{2}{*}{\multicolumn{2}{|c|}{ Total }} & Count & 242 & 151 & 68 & 24 & 15 & 500 \\
\hline & & $\%$ of Total & $48.4 \%$ & $30.2 \%$ & $13.6 \%$ & $4.8 \%$ & $3.0 \%$ & $100.0 \%$ \\
\hline
\end{tabular}

Interpretation: from the above crosstab, it can said that out of total 500 respondents (Software Professionals), $48.4 \%$ respondents strongly agreed, $30.2 \%$ respondents agreed, $13.6 \%$ respondents were neutral, $4.8 \%$ respondents disagreed and 3.0\% respondents strongly disagreed that I am aware of what I think and feel and how $I$ act in a situation.

4.2.4 Analysis:Analysis of the relationship between I am emotionally intelligent and I think a lot before I act.

H0: The two factors are independent.

H1: The two factors are not independent (associated).

Tool Used: Chi Square Test (Analyze $\rightarrow$ Descriptive Statistics $\rightarrow$ Crosstabs)

Table 4.10Chi-Square Tests

\begin{tabular}{|l|l|l|l|}
\hline Chi-Square Tests & Asymp. Sig. (2-sided) \\
\hline & Value & df & Asy \\
\hline Pearson Chi-Square & $117.071^{\mathrm{a}}$ & 16 & .000 \\
\hline Likelihood Ratio & 70.200 & 16 & .000 \\
\hline Linear-by-Linear Association & 26.000 & 1 & .000 \\
\hline N of Valid Cases & 500 & & \\
\hline a. 12 cells (48.0\%) have expected count less than 5. The minimum expected count is .12. \\
\hline
\end{tabular}


Topic: A study of the association between self-awareness, personal \& social competence with the

Table 4.11Symmetric Measures

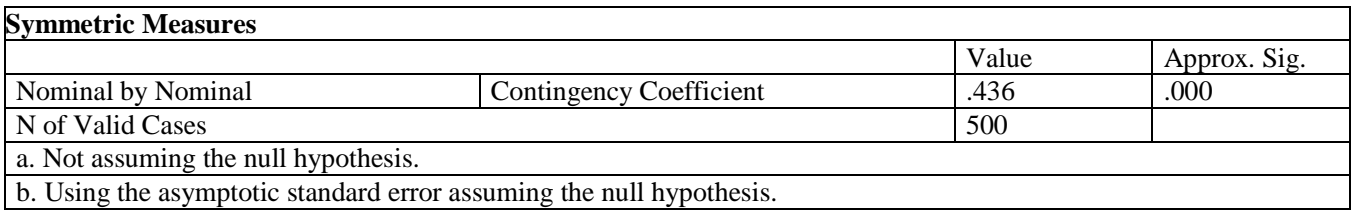

Interpretation: From the table we find out that asymptotic significance for Pearson Chi Square comes out to be 0.000 (less than 0.05 ) so we reject null hypothesis at $5 \%$ level of significance. Hence it can be concluded that two variables are associated.

Table 4.12Crosstab: I am emotionally intelligent- I think a lot before I act.

\begin{tabular}{|c|c|c|c|c|c|c|c|c|}
\hline & & & \multicolumn{5}{|c|}{ I think a lot before I act. } & \multirow[t]{2}{*}{ Total } \\
\hline & & & Strongly agree & Agree & Neutral & Disagree & Strongly disagree & \\
\hline \multirow{10}{*}{$\begin{array}{l}\text { am } \\
\text { intelligent. }\end{array}$} & \multirow{2}{*}{ strongly agree } & count & 70 & 29 & 31 & 4 & 0 & 134 \\
\hline & & $\%$ of total & $14.0 \%$ & $5.8 \%$ & $6.2 \%$ & $0.8 \%$ & $0.0 \%$ & $26.8 \%$ \\
\hline & \multirow{2}{*}{ agree } & count & 70 & 81 & 38 & 9 & 0 & 198 \\
\hline & & $\%$ of total & $14.0 \%$ & $16.2 \%$ & $7.6 \%$ & $1.8 \%$ & $0.0 \%$ & $39.6 \%$ \\
\hline & \multirow{2}{*}{ y neutral } & count & 46 & 56 & 34 & 3 & 3 & 142 \\
\hline & & $\%$ of total & $9.2 \%$ & $11.2 \%$ & $6.8 \%$ & $0.6 \%$ & $0.6 \%$ & $28.4 \%$ \\
\hline & \multirow{2}{*}{ disagree } & count & 3 & 7 & 7 & 3 & 0 & 20 \\
\hline & & $\%$ of total & $0.6 \%$ & $1.4 \%$ & $1.4 \%$ & $0.6 \%$ & $0.0 \%$ & $4.0 \%$ \\
\hline & \multirow{2}{*}{ strongly disagree } & count & 0 & 3 & 3 & 0 & 0 & 6 \\
\hline & & $\%$ of Total & $0.0 \%$ & $0.6 \%$ & $0.6 \%$ & $0.0 \%$ & $0.0 \%$ & $1.2 \%$ \\
\hline \multirow{2}{*}{\multicolumn{2}{|c|}{ Total }} & Count & 189 & 176 & 113 & 19 & 3 & 500 \\
\hline & & $\%$ of Total & $37.8 \%$ & $35.2 \%$ & $22.6 \%$ & $3.8 \%$ & $0.6 \%$ & $100.0 \%$ \\
\hline
\end{tabular}

Interpretation: from the above crosstab, it can said that out of total 500 respondents (Software Professionals), $37.8 \%$ respondents strongly agreed, $35.2 \%$ respondents agreed, $22.6 \%$ respondents were neutral, $3.8 \%$ respondents disagreed and $0.6 \%$ respondents strongly disagreed that I am now aware of what I think and feel and how $I$ act in a situation.

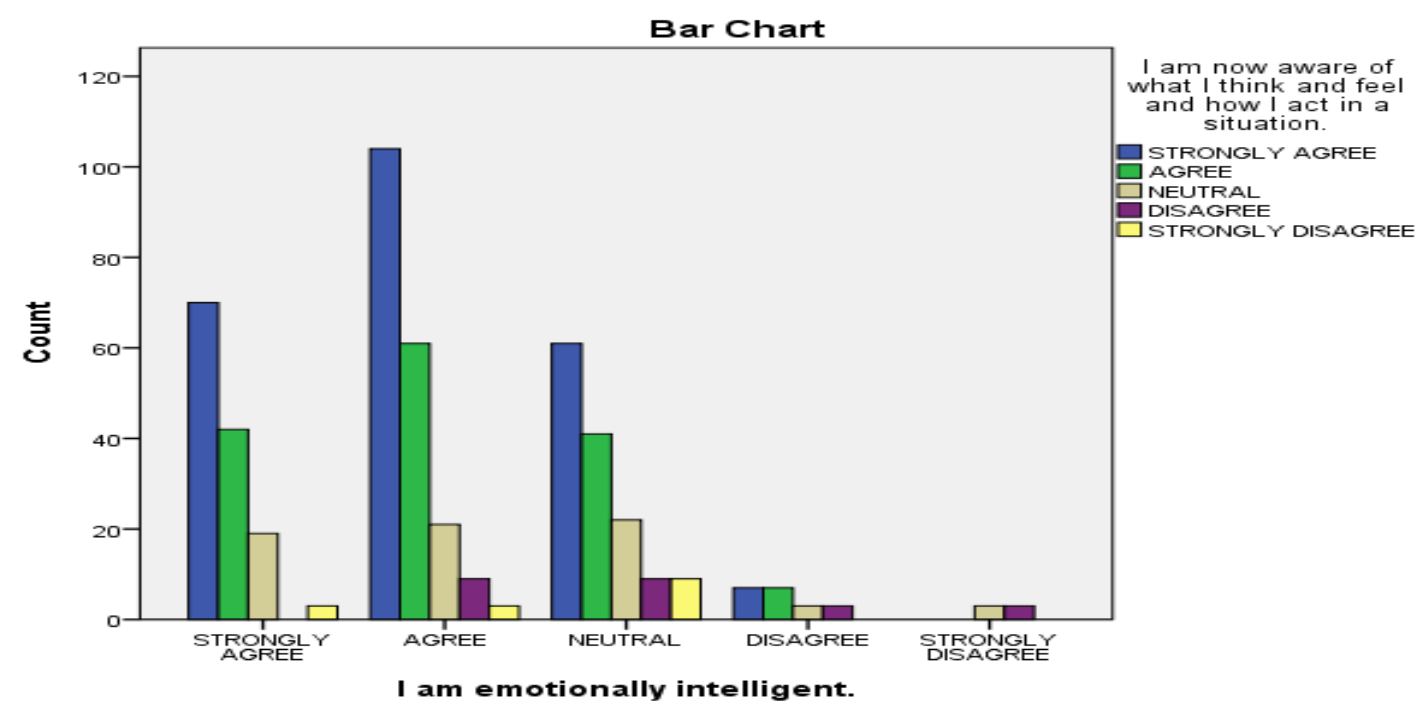

4.2.5 Analysis: Analysis of the relationship between emotional intelligence andI consider all the possibilities before making a decision.

H0: The two factors are independent.

H1: The two factors are not independent (associated).

Tool Used: Chi Square Test (Analyze $\rightarrow$ Descriptive Statistics $\rightarrow$ Crosstabs)

Table 4.13Chi-Square Tests

\begin{tabular}{|l|l|l|l|}
\hline Chi-Square Tests & Value & df & Asymp. Sig. (2-sided) \\
\hline Pearson Chi-Square & $44.232^{\mathrm{a}}$ & 16 & .000 \\
\hline Likelihood Ratio & 44.476 & 16 & .000 \\
\hline Linear-by-Linear Association & 13.769 & 1 & .000 \\
\hline N of Valid Cases & 500 & & \\
\hline a. 11 cells (44.0\%) have expected count less than 5. The minimum expected count is .04. \\
\hline
\end{tabular}


Topic: A study of the association between self-awareness, personal \& social competence with the

Table 4.14Symmetric Measures

\begin{tabular}{|c|c|c|c|}
\hline \multicolumn{4}{|l|}{ Symmetric Measures } \\
\hline & & Value & Approx. Sig. \\
\hline Nominal by Nominal & Contingency Coefficient & .285 & .000 \\
\hline \multicolumn{2}{|l|}{$\mathrm{N}$ of Valid Cases } & 500 & \\
\hline
\end{tabular}

Interpretation: From the table we find out that asymptotic significance for Pearson Chi Square comes out to be 0.000 (less than 0.05 ) so we reject null hypothesis at $5 \%$ level of significance. Hence it can be concluded that two variables are associated.

Table 4.15Crosstab: I am emotionally intelligent. * I consider all the possibilities before making a decision.

\begin{tabular}{|c|c|c|c|c|c|c|c|c|}
\hline \multicolumn{9}{|l|}{ Crosstab } \\
\hline & & & \multicolumn{5}{|c|}{ I consider all the possibilities before making a decision. } & \multirow[t]{2}{*}{ Total } \\
\hline & & & Strongly agree & Agree & Neutral & Disagree & Strongly disagree & \\
\hline \multirow{10}{*}{$\begin{array}{l}\text { I am } \\
\text { emotionally } \\
\text { intelligent. }\end{array}$} & \multirow{2}{*}{$\begin{array}{l}\text { Strongly } \\
\text { agree }\end{array}$} & Count & 45 & 58 & 24 & 7 & 0 & 134 \\
\hline & & $\%$ of Total & $9.0 \%$ & $11.6 \%$ & $4.8 \%$ & $1.4 \%$ & $0.0 \%$ & $26.8 \%$ \\
\hline & \multirow{2}{*}{ Agree } & Count & 26 & 96 & 55 & 17 & 4 & 198 \\
\hline & & $\%$ of Total & $5.2 \%$ & $19.2 \%$ & $11.0 \%$ & $3.4 \%$ & $0.8 \%$ & $39.6 \%$ \\
\hline & \multirow{2}{*}{ Neutral } & Count & 18 & 71 & 33 & 17 & 3 & 142 \\
\hline & & $\%$ of Total & $3.6 \%$ & $14.2 \%$ & $6.6 \%$ & $3.4 \%$ & $0.6 \%$ & $28.4 \%$ \\
\hline & \multirow{2}{*}{ Disagree } & Count & 0 & 14 & 6 & 0 & 0 & 20 \\
\hline & & $\%$ of Total & $0.0 \%$ & $2.8 \%$ & $1.2 \%$ & $0.0 \%$ & $0.0 \%$ & $4.0 \%$ \\
\hline & \multirow{2}{*}{$\begin{array}{l}\text { Strongly } \\
\text { disagree }\end{array}$} & Count & 0 & 0 & 3 & 0 & 3 & 6 \\
\hline & & $\%$ of Total & $0.0 \%$ & $0.0 \%$ & $0.6 \%$ & $0.0 \%$ & $0.6 \%$ & $1.2 \%$ \\
\hline \multirow{2}{*}{\multicolumn{2}{|c|}{ Total }} & Count & 89 & 239 & 121 & 41 & 10 & 500 \\
\hline & & $\%$ of Total & $17.8 \%$ & $47.8 \%$ & $24.2 \%$ & $8.2 \%$ & $2.0 \%$ & $100.0 \%$ \\
\hline
\end{tabular}

Interpretation: from the above crosstab, it can said that out of total 500 respondents (Software Professionals), $17.8 \%$ respondents strongly agreed, $47.8 \%$ respondents agreed, $24.2 \%$ respondents were neutral, $8.2 \%$ respondents disagreed and $2 \%$ respondents strongly disagreed that I am now aware of what I think and feel and how $I$ act in a situation.

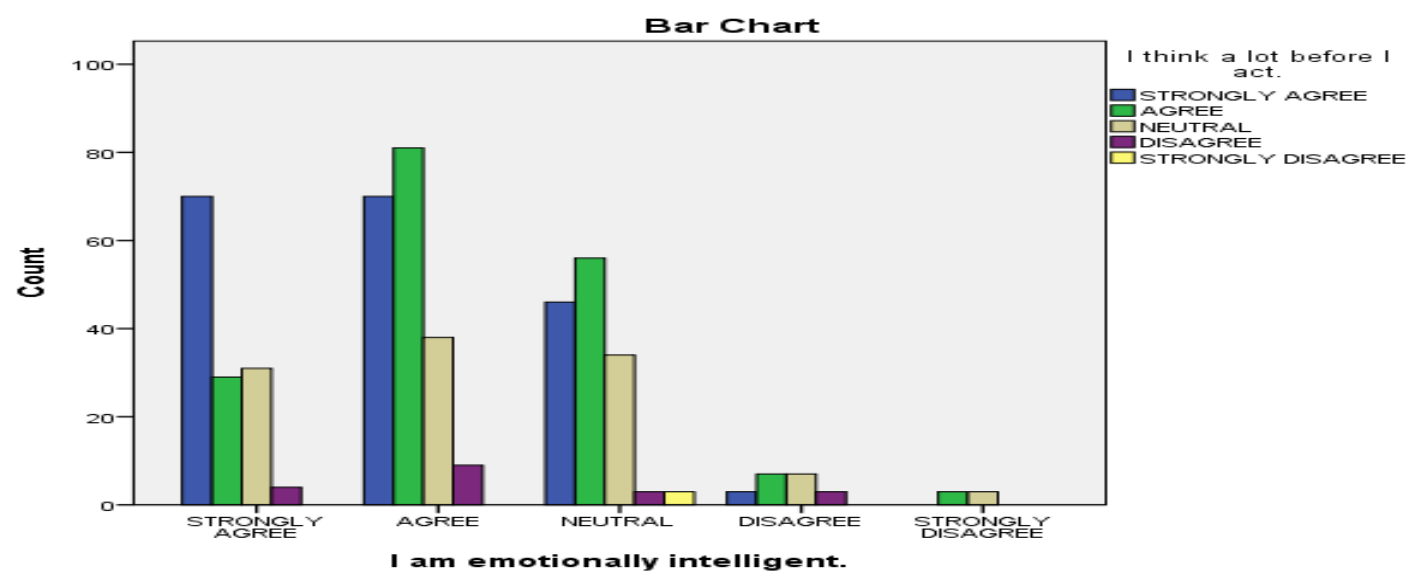

4.2.6 Analysis: Analysis of the relationship between emotional intelligence andI know what motivates and satisfies me.

H0: The two factors are independent.

H1: The two factors are not independent (associated).

Tool Used: Chi Square Test (Analyze $\rightarrow$ Descriptive Statistics $\rightarrow$ Crosstabs)

Table 4.16Chi-Square Tests

\section{Chi-Square Tests}

\begin{tabular}{|l|l|l|}
\hline Value & df & Asymp. Sig. (2-sided)
\end{tabular}


Topic: A study of the association between self-awareness, personal \& social competence with the

\begin{tabular}{|l|l|l|l|}
\hline Pearson Chi-Square & $137.784^{\mathrm{a}}$ & 16 & .000 \\
\hline Likelihood Ratio & 82.883 & 16 & .000 \\
\hline Linear-by-Linear Association & 42.268 & 1 & .000 \\
\hline N of Valid Cases & 500 & & \\
\hline a. 11 cells (44.0\%) have expected count less than 5. The minimum expected count is .12. \\
\hline
\end{tabular}

a. 11 cells $(44.0 \%)$ have expected count less than 5 . The minimum expected count is . 12

\begin{tabular}{|c|c|c|c|}
\hline \multicolumn{4}{|l|}{ Symmetric Measures } \\
\hline & & Value & Approx. Sig \\
\hline Nominal by Nominal & Contingency Coefficient & .465 & .000 \\
\hline \multicolumn{2}{|l|}{$\mathrm{N}$ of Valid Cases } & 500 & \\
\hline \multicolumn{4}{|l|}{ a. Not assuming the nul } \\
\hline
\end{tabular}

Interpretation: From the table we find out that asymptotic significance for Pearson Chi Square comes out to be 0.000 (less than 0.05 ) so we reject null hypothesis at 5\% level of significance. Hence it can be concluded that two variables are associated.

Table 4.18Crosstab: I know what motivates and satisfy me.

\begin{tabular}{|c|c|c|c|c|c|c|c|c|}
\hline \multicolumn{9}{|l|}{ Crosstab } \\
\hline & & & I know what $\mathrm{m}$ & tivates a & satisfies & & & Total \\
\hline & & & Strongly agree & Agree & Neutral & Disagree & Strongly disagree & \\
\hline \multirow{10}{*}{$\begin{array}{l}\text { I am } \\
\text { emotionally } \\
\text { intelligent. }\end{array}$} & \multirow{2}{*}{$\begin{array}{l}\text { Strongly } \\
\text { agree }\end{array}$} & Count & 27 & 71 & 32 & 4 & 0 & 134 \\
\hline & & $\%$ of Total & $5.4 \%$ & $14.2 \%$ & $6.4 \%$ & $0.8 \%$ & $0.0 \%$ & $26.8 \%$ \\
\hline & \multirow{2}{*}{ Agree } & Count & 19 & 98 & 71 & 10 & 0 & 198 \\
\hline & & $\%$ of Total & $3.8 \%$ & $19.6 \%$ & $14.2 \%$ & $2.0 \%$ & $0.0 \%$ & $39.6 \%$ \\
\hline & \multirow{2}{*}{ Neutral } & Count & 9 & 69 & 41 & 19 & 4 & 142 \\
\hline & & $\%$ of Total & $1.8 \%$ & $13.8 \%$ & $8.2 \%$ & $3.8 \%$ & $0.8 \%$ & $28.4 \%$ \\
\hline & \multirow{2}{*}{ Disagree } & Count & 0 & 7 & 7 & 0 & 6 & 20 \\
\hline & & $\%$ of Total & $0.0 \%$ & $1.4 \%$ & $1.4 \%$ & $0.0 \%$ & $1.2 \%$ & $4.0 \%$ \\
\hline & \multirow{2}{*}{$\begin{array}{l}\text { Strongly } \\
\text { disagree }\end{array}$} & Count & 0 & 3 & 0 & 3 & 0 & 6 \\
\hline & & $\%$ of Total & $0.0 \%$ & $0.6 \%$ & $0.0 \%$ & $0.6 \%$ & $0.0 \%$ & $1.2 \%$ \\
\hline \multirow{2}{*}{\multicolumn{2}{|c|}{ Total }} & Count & 55 & 248 & 151 & 36 & 10 & 500 \\
\hline & & $\%$ of Total & $11.0 \%$ & $49.6 \%$ & $30.2 \%$ & $7.2 \%$ & $2.0 \%$ & $100.0 \%$ \\
\hline
\end{tabular}

Interpretation: from the above crosstab, it can said that out of total 500 respondents (Software Professionals), $11.0 \%$ respondents strongly agreed, $49.6 \%$ respondents agreed, $30.2 \%$ respondents were neutral, $7.2 \%$ respondents disagreed and $2 \%$ respondents strongly disagreed that I know what motivates and satisfy me.

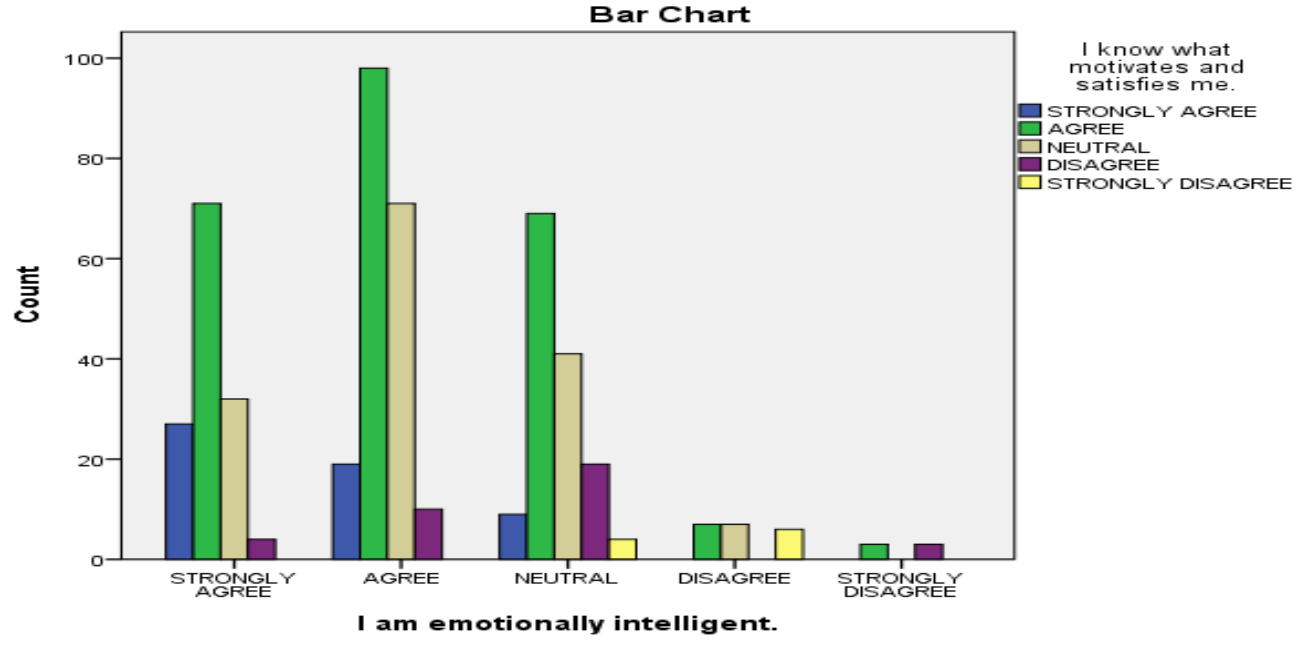

From the above results it can be seen that there was an association between all the independent variables of Selfawareness and the dependent variable-Emotional Intelligence.

Hence, it can be said that our Alternate Hypothesis (H1) -1 is accepted andNull Hypothesis (H0) -1 is rejected and Research Objective-1 is fulfilled.

4.3. CHI Square Analysis: Analysis of the Association between Emotional Intelligence and Personal Competence.

4.3.1 Analysis: Personal Competence: Analysis of the Association between emotional intelligence andI have the ability to tackle all problems with analytical approach. 
H0: The two factors are independent.

H1: The two factors are not independent (associated).

Tool Used: Chi Square Test (Analyze $\rightarrow$ Descriptive Statistics $\rightarrow$ Crosstabs)

Table 4.19Chi-Square Tests

\begin{tabular}{|l|l|l|l|}
\hline Chi-Square Tests & Value & df & Asymp. Sig. (2-sided) \\
\hline & $43.966^{\mathrm{a}}$ & 12 & .000 \\
\hline Pearson Chi-Square & 46.852 & 12 & .000 \\
\hline Likelihood Ratio & 2.904 & 1 & .088 \\
\hline Linear-by-Linear Association & 500 & & \\
\hline N of Valid Cases & \multicolumn{1}{l}{. The minimum expected count is .40. } \\
\hline a. 6 cells (30.0\%) have expected count less than 5. The \\
\hline
\end{tabular}

Table 4.20Symmetric Measures

\begin{tabular}{|l|l|l|l|}
\hline \multicolumn{2}{|l|}{ Symmetric Measures } & Value & Approx. Sig. \\
\hline Nominal by Nominal & Contingency Coefficient & .284 & .000 \\
\hline N of Valid Cases & 500 & \\
\hline a. Not assuming the null hypothesis. & \\
\hline b. Using the asymptotic standard error assuming the null hypothesis. & \\
\hline
\end{tabular}

Interpretation: From the table we find out that asymptotic significance for Pearson Chi Square comes out to be 0.000 (less than 0.05 ) so we reject null hypothesis at $5 \%$ level of significance. Hence it can be concluded that two variables are associated.

Table 4.21Crosstab: I am emotionally intelligent. *I have the ability to tackle all problems with analytical approach.

\begin{tabular}{|c|c|c|c|c|c|c|c|}
\hline \multicolumn{8}{|l|}{ Crosstab } \\
\hline & & & \multicolumn{4}{|c|}{$\begin{array}{l}\text { I have the ability to tackle all problems with } \\
\text { analytical approach. }\end{array}$} & \multirow[t]{2}{*}{ Total } \\
\hline & & & Strongly agree & Agree & Neutral & Disagree & \\
\hline \multirow{10}{*}{$\begin{array}{l}\text { I am emotionally } \\
\text { intelligent. }\end{array}$} & \multirow{2}{*}{ Strongly agree } & Count & 27 & 51 & 48 & 8 & 134 \\
\hline & & $\%$ of Total & $5.4 \%$ & $10.2 \%$ & $9.6 \%$ & $1.6 \%$ & $26.8 \%$ \\
\hline & \multirow{2}{*}{ Agree } & Count & 18 & 102 & 64 & 14 & 198 \\
\hline & & $\%$ of Total & $3.6 \%$ & $20.4 \%$ & $12.8 \%$ & $2.8 \%$ & $39.6 \%$ \\
\hline & \multirow{2}{*}{ Neutral } & Count & 7 & 76 & 48 & 11 & 142 \\
\hline & & $\%$ of Total & $1.4 \%$ & $15.2 \%$ & $9.6 \%$ & $2.2 \%$ & $28.4 \%$ \\
\hline & \multirow{2}{*}{ Disagree } & Count & 0 & 17 & 3 & 0 & 20 \\
\hline & & $\%$ of Total & $0.0 \%$ & $3.4 \%$ & $0.6 \%$ & $0.0 \%$ & $4.0 \%$ \\
\hline & \multirow{2}{*}{ Strongly disagree } & Count & 0 & 0 & 6 & 0 & 6 \\
\hline & & $\%$ of Total & $0.0 \%$ & $0.0 \%$ & $1.2 \%$ & $0.0 \%$ & $1.2 \%$ \\
\hline \multirow{2}{*}{\multicolumn{2}{|c|}{ Total }} & Count & 52 & 246 & 169 & 33 & 500 \\
\hline & & $\%$ of Total & $10.4 \%$ & $49.2 \%$ & $33.8 \%$ & $6.6 \%$ & $100.0 \%$ \\
\hline
\end{tabular}

Interpretation: from the above crosstab, it can said that out of total 500 respondents (Software Professionals), $10.4 \%$ respondents strongly agreed, $49.2 \%$ respondents agreed, $33.8 \%$ respondents were neutral, $6.6 \%$ respondents disagreed and $2 \%$ respondents strongly disagreed that $\mathbf{I}$ have the ability to tackle all problems with analytical approach. 


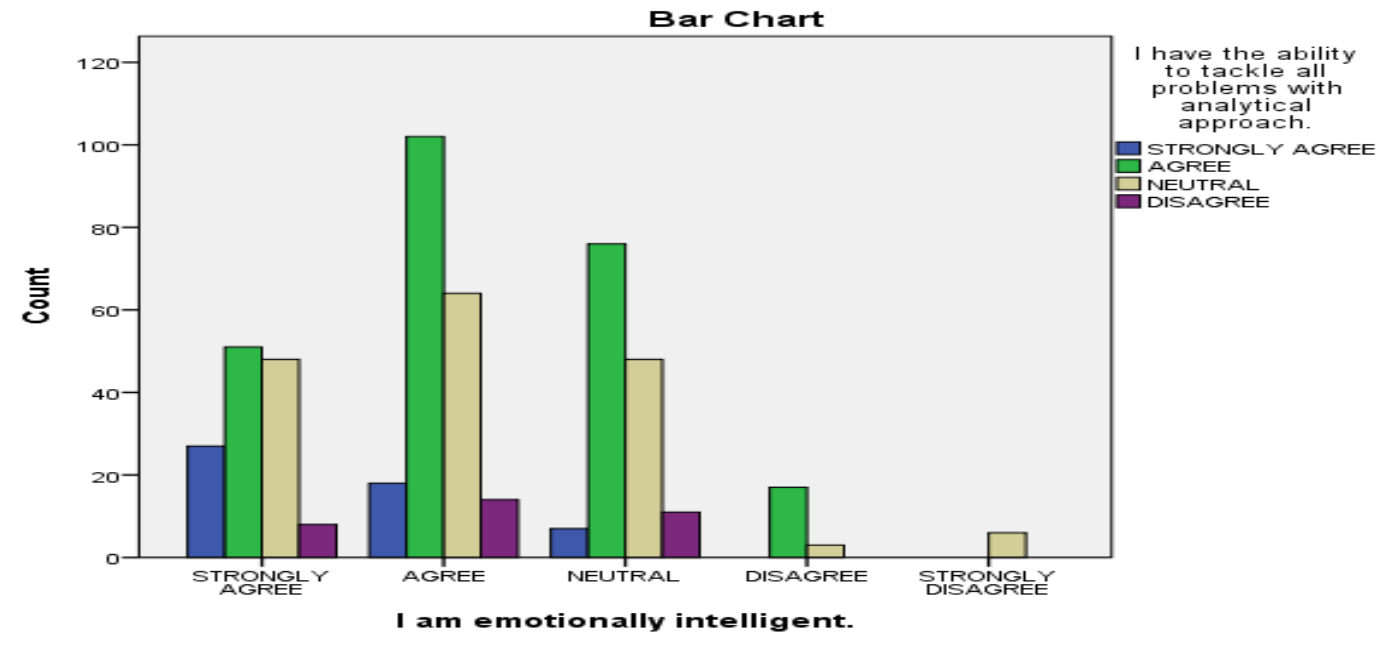

4.3.2 Analysis: Analysis of the relationship between emotional intelligence andI build faith through my reliability.

H0: The two factors are independent.

H1: The two factors are not independent (associated).

Tool Used: Chi Square Test (Analyze $\rightarrow$ Descriptive Statistics $\rightarrow$ Crosstabs)

Table 4.22Chi-Square Tests

\begin{tabular}{|l|l|l|l|}
\hline \multicolumn{4}{|l|}{ Chi-Square Tests } \\
\hline \multicolumn{2}{|l|}{ Value } & df & Asymp. Sig. (2-sided) \\
\hline Pearson Chi-Square & $105.682^{\mathrm{a}}$ & 16 & .000 \\
\hline Likelihood Ratio & 75.199 & 16 & .000 \\
\hline Linear-by-Linear Association & 5.156 & 1 & .023 \\
\hline N of Valid Cases & 500 & & \\
\hline a. 11 cells (44.0\%) have expected count less than & 5. The minimum expected count is .13. \\
\hline
\end{tabular}

Table 4.23Symmetric Measures

\begin{tabular}{|c|c|c|c|}
\hline \multicolumn{4}{|l|}{ Symmetric Measures } \\
\hline & & Value & Approx. Sig. \\
\hline Nominal by Nominal & Contingency Coefficient & .418 & .000 \\
\hline \multicolumn{2}{|l|}{$\mathrm{N}$ of Valid Cases } & 500 & \\
\hline \multicolumn{4}{|c|}{ a. Not assuming the null hypothesis. } \\
\hline
\end{tabular}

Interpretation: From the table we find out that asymptotic significance for Pearson Chi Square comes out to be 0.000 (less than 0.05 ) so we reject null hypothesis at $5 \%$ level of significance. Hence it can be concluded that two variables are associated.

Table 4.24Crosstab: I build faith through my reliability.

\begin{tabular}{|c|c|c|c|c|c|c|c|c|}
\hline \multicolumn{9}{|l|}{ Crosstab } \\
\hline & & & \multicolumn{5}{|c|}{ I build faith through my reliability. } & \multirow[t]{2}{*}{ Total } \\
\hline & & & Strongly agree & Agree & Neutral & Disagree & Strongly disagree & \\
\hline \multirow{10}{*}{$\begin{array}{l}\text { I am emotionally } \\
\text { intelligent. }\end{array}$} & \multirow{2}{*}{$\begin{array}{l}\text { Strongly } \\
\text { agree }\end{array}$} & Count & 19 & 75 & 36 & 0 & 4 & 134 \\
\hline & & $\%$ of Total & $3.8 \%$ & $15.0 \%$ & $7.2 \%$ & $0.0 \%$ & $0.8 \%$ & $26.8 \%$ \\
\hline & \multirow{2}{*}{ Agree } & Count & 27 & 91 & 65 & 11 & 4 & 198 \\
\hline & & $\%$ of Total & $5.4 \%$ & $18.2 \%$ & $13.0 \%$ & $2.2 \%$ & $0.8 \%$ & $39.6 \%$ \\
\hline & \multirow{2}{*}{ Neutral } & Count & 7 & 74 & 46 & 15 & 0 & 142 \\
\hline & & $\%$ of Total & $1.4 \%$ & $14.8 \%$ & $9.2 \%$ & $3.0 \%$ & $0.0 \%$ & $28.4 \%$ \\
\hline & \multirow{2}{*}{ Disagree } & Count & 3 & 17 & 0 & 0 & 0 & 20 \\
\hline & & $\%$ of Total & $0.6 \%$ & $3.4 \%$ & $0.0 \%$ & $0.0 \%$ & $0.0 \%$ & $4.0 \%$ \\
\hline & \multirow{2}{*}{$\begin{array}{l}\text { Strongly } \\
\text { disagree }\end{array}$} & Count & 0 & 3 & 0 & 0 & 3 & 6 \\
\hline & & $\%$ of Total & $0.0 \%$ & $0.6 \%$ & $0.0 \%$ & $0.0 \%$ & $0.6 \%$ & $1.2 \%$ \\
\hline \multirow{2}{*}{\multicolumn{2}{|c|}{ Total }} & Count & 56 & 260 & 147 & 26 & 11 & 500 \\
\hline & & $\%$ of Total & $11.2 \%$ & $52.0 \%$ & $29.4 \%$ & $5.2 \%$ & $2.2 \%$ & $100.0 \%$ \\
\hline
\end{tabular}

Interpretation: from the above crosstab, it can said that out of total 500 respondents (Software Professionals), $11.2 \%$ respondents strongly agreed, $52 \%$ respondents agreed, $29.4 \%$ respondents were neutral, $5.2 \%$ 

respondents disagreed and $2.2 \%$ respondents strongly disagreed that I build faith through my reliability.

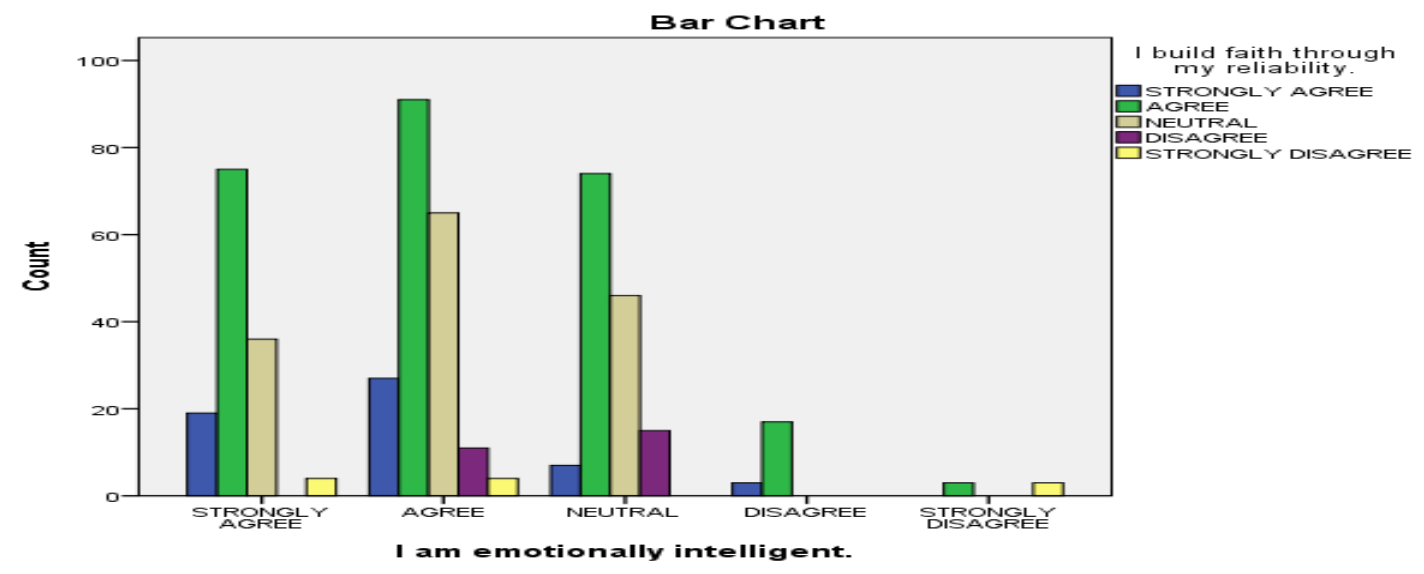

4.3.3.Analysis: Analysis of the relationship between emotional intelligence andI take responsibility for my personal performanceof the software professional in India.

H0: The two factors are independent.

H1: The two factors are not independent (associated).

Tool Used: Chi Square Test (Analyze $\rightarrow$ Descriptive Statistics $\rightarrow$ Crosstabs)

Table 4.25 Chi-Square Tests

\begin{tabular}{|l|l|l|l|}
\hline Chi-Square Tests & Value & df & Asymp. Sig. (2-sided) \\
\hline & $125.948^{\mathrm{a}}$ & 16 & .000 \\
\hline Pearson Chi-Square & 98.677 & 16 & .000 \\
\hline Likelihood Ratio & 8.019 & 1 & .005 \\
\hline Linear-by-Linear Association & 500 & & \\
\hline N of Valid Cases & & \\
\hline a. 10 cells (40.0\%) have expected count less than 5. The minimum expected count is .18. \\
\hline
\end{tabular}

Table 4.26Symmetric Measures

\begin{tabular}{|l|l|l|l|}
\hline \multicolumn{2}{|l|}{ Symmetric Measures } & Value & Approx. Sig. \\
\hline \multicolumn{2}{|l|}{} & .449 & .000 \\
\hline Nominal by Nominal & Contingency Coefficient & 500 & \\
\hline N of Valid Cases & & \\
\hline a. Not assuming the null hypothesis. \\
\hline b. Using the asymptotic standard error assuming the null hypothesis. \\
\hline
\end{tabular}

Interpretation: From the table we find out that asymptotic significance for Pearson Chi Square comes out to be 0.000 (less than 0.05 ) so we reject null hypothesis at $5 \%$ level of significance. Hence it can be concluded that two variables are associated.

Table 4.27Crosstab: I take responsibility for my personal performance.

\begin{tabular}{|c|c|c|c|c|c|c|c|c|}
\hline \multicolumn{9}{|l|}{ Crosstab } \\
\hline & & & I take responsib & ty for $m$ & personal & erformanc & & Total \\
\hline & & & Strongly agree & Agree & Neutral & Disagree & Strongly disagree & \\
\hline \multirow{10}{*}{$\begin{array}{l}\text { I am } \\
\text { emotionally } \\
\text { intelligent. }\end{array}$} & \multirow{2}{*}{$\begin{array}{l}\text { Strongly } \\
\text { agree }\end{array}$} & Count & 34 & 55 & 41 & 0 & 4 & 134 \\
\hline & & $\%$ of Total & $6.8 \%$ & $11.0 \%$ & $8.2 \%$ & $0.0 \%$ & $0.8 \%$ & $26.8 \%$ \\
\hline & \multirow{2}{*}{ Agree } & Count & 16 & 117 & 54 & 3 & 8 & 198 \\
\hline & & $\%$ of Total & $3.2 \%$ & $23.4 \%$ & $10.8 \%$ & $0.6 \%$ & $1.6 \%$ & $39.6 \%$ \\
\hline & \multirow{2}{*}{ Neutral } & Count & 25 & 58 & 35 & 24 & 0 & 142 \\
\hline & & $\%$ of Total & $5.0 \%$ & $11.6 \%$ & $7.0 \%$ & $4.8 \%$ & $0.0 \%$ & $28.4 \%$ \\
\hline & \multirow{2}{*}{ Disagree } & Count & 3 & 11 & 6 & 0 & 0 & 20 \\
\hline & & $\%$ of Total & $0.6 \%$ & $2.2 \%$ & $1.2 \%$ & $0.0 \%$ & $0.0 \%$ & $4.0 \%$ \\
\hline & \multirow{2}{*}{$\begin{array}{l}\text { Strongly } \\
\text { disagree }\end{array}$} & Count & 0 & 3 & 0 & 0 & 3 & 6 \\
\hline & & $\%$ of Total & $0.0 \%$ & $0.6 \%$ & $0.0 \%$ & $0.0 \%$ & $0.6 \%$ & $1.2 \%$ \\
\hline \multirow{2}{*}{\multicolumn{2}{|c|}{ Total }} & Count & 78 & 244 & 136 & 27 & 15 & 500 \\
\hline & & $\%$ of Total & $15.6 \%$ & $48.8 \%$ & $27.2 \%$ & $5.4 \%$ & $3.0 \%$ & $100.0 \%$ \\
\hline
\end{tabular}

Interpretation: from the above crosstab, it can said that out of total 500 respondents (Software Professionals), $15.6 \%$ respondents strongly agreed, $48.8 \%$ respondents agreed, $27.2 \%$ respondents were neutral, $5.4 \%$ respondents disagreed and $3 \%$ respondents strongly disagreed that I take responsibility for my personal performance. 


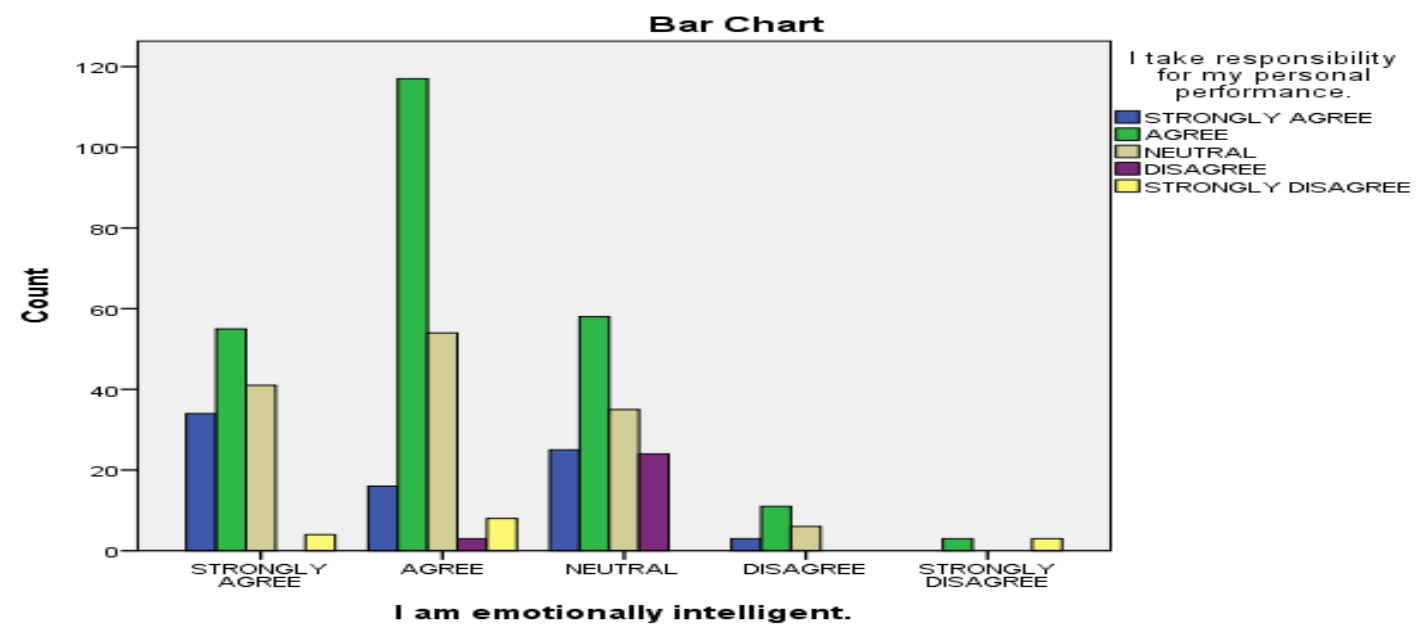

4.3.4. Analysis: Analysis of the relationship between emotional intelligence andI am able to maintain the standards of honesty and integrityof the software professional in India.

H0: The two factors are independent.

H1: The two factors are not independent (associated).

Tool Used: Chi Square Test (Analyze $\rightarrow$ Descriptive Statistics $\rightarrow$ Crosstabs)

Table 4.28Chi-Square Tests
\begin{tabular}{|l|l|l|l|}
\hline Chi-Square Tests & Value & df & Asymp. Sig. (2-sided) \\
\hline & $61.981^{\mathrm{a}}$ & 16 & .000 \\
\hline Pearson Chi-Square & 60.118 & 16 & .000 \\
\hline Likelihood Ratio & 3.093 & 1 & .079 \\
\hline Linear-by-Linear Association & 500 & & \\
\hline N of Valid Cases & a. 10 cells (40.0\%) have expected count less than 5. The minimum expected count is .18. \\
\hline
\end{tabular}

Table 4.29Symmetric Measures

\begin{tabular}{|l|l|l|l|}
\hline \multicolumn{2}{|l|}{ Symmetric Measures } & Value & Approx. Sig. \\
\hline Nominal by Nominal & Contingency Coefficient & .332 & .000 \\
\hline N of Valid Cases & 500 & \\
\hline a. Not assuming the null hypothesis. & \\
\hline b. Using the asymptotic standard error assuming the null hypothesis. & \\
\hline
\end{tabular}

Interpretation: From the table we find out that asymptotic significance for Pearson Chi Square comes out to be 0.000 (less than 0.05 ) so we reject null hypothesis at 5\% level of significance. Hence it can be concluded that two variables are associated.

Table 4.30Crosstab: I am able to maintain the standards of honesty and integrity.

\begin{tabular}{|c|c|c|c|c|c|c|c|c|}
\hline \multicolumn{9}{|l|}{ Crosstab } \\
\hline & & & \multicolumn{5}{|c|}{ I am able to maintain the standards of honesty and integrity. } & \multirow[t]{2}{*}{ Total } \\
\hline & & & Strongly agree & Agree & Neutral & Disagree & Strongly disagree & \\
\hline \multirow{10}{*}{$\begin{array}{l}\text { I am } \\
\text { emotionally } \\
\text { intelligent. }\end{array}$} & \multirow{2}{*}{$\begin{array}{l}\text { Strongly } \\
\text { agree }\end{array}$} & Count & 27 & 61 & 21 & 21 & 4 & 134 \\
\hline & & $\%$ of Total & $5.4 \%$ & $12.2 \%$ & $4.2 \%$ & $4.2 \%$ & $0.8 \%$ & $26.8 \%$ \\
\hline & \multirow{2}{*}{ Agree } & Count & 20 & 104 & 63 & 7 & 4 & 198 \\
\hline & & $\%$ of Total & $4.0 \%$ & $20.8 \%$ & $12.6 \%$ & $1.4 \%$ & $0.8 \%$ & $39.6 \%$ \\
\hline & \multirow{2}{*}{ Neutral } & Count & 17 & 54 & 54 & 10 & 7 & 142 \\
\hline & & $\%$ of Total & $3.4 \%$ & $10.8 \%$ & $10.8 \%$ & $2.0 \%$ & $1.4 \%$ & $28.4 \%$ \\
\hline & \multirow{2}{*}{ Disagree } & Count & 4 & 6 & 10 & 0 & 0 & 20 \\
\hline & & $\%$ of Total & $0.8 \%$ & $1.2 \%$ & $2.0 \%$ & $0.0 \%$ & $0.0 \%$ & $4.0 \%$ \\
\hline & \multirow{2}{*}{$\begin{array}{l}\text { Strongly } \\
\text { disagree }\end{array}$} & Count & 0 & 3 & 0 & 3 & 0 & 6 \\
\hline & & $\%$ of Total & $0.0 \%$ & $0.6 \%$ & $0.0 \%$ & $0.6 \%$ & $0.0 \%$ & $1.2 \%$ \\
\hline \multirow{2}{*}{\multicolumn{2}{|c|}{ Total }} & Count & 68 & 228 & 148 & 41 & 15 & 500 \\
\hline & & $\%$ of Total & $13.6 \%$ & $45.6 \%$ & $29.6 \%$ & $8.2 \%$ & $3.0 \%$ & $100.0 \%$ \\
\hline
\end{tabular}

Interpretation: from the above crosstab, it can said that out of total 500 respondents (Software Professionals), $13.6 \%$ respondents strongly agreed, $45.6 \%$ respondents agreed, $29.6 \%$ respondents were neutral, $8.2 \%$ respondents disagreed and 3\% respondents strongly disagreed that $\mathbf{I}$ am able to maintain the standards of honesty and integrity. 


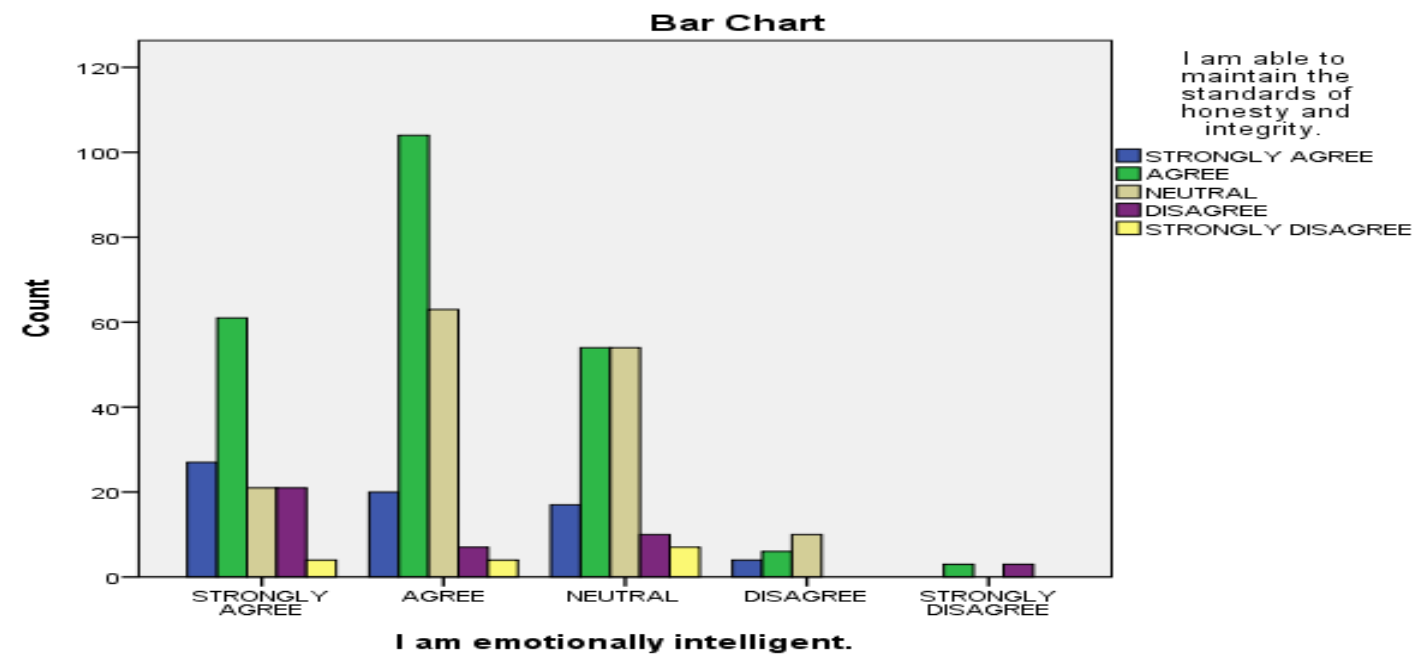

4.3.5. Analysis: Analysis of the relationship between I am emotionally intelligent and I am highly organized in my work.

H0: The two factors are independent.

H1: The two factors are not independent (associated).

Tool Used: Chi Square Test (Analyze $\rightarrow$ Descriptive Statistics $\rightarrow$ Crosstabs)

Table 4.31Chi-Square Tests

\begin{tabular}{|c|c|c|c|}
\hline \multicolumn{4}{|l|}{ Chi-Square Tests } \\
\hline & Value & $\mathrm{df}$ & Asymp. Sig. (2-sided) \\
\hline Pearson Chi-Square & $47.637^{\mathrm{a}}$ & 16 & .000 \\
\hline Likelihood Ratio & 52.912 & 16 & .000 \\
\hline Linear-by-Linear Association & 2.823 & 1 & .093 \\
\hline $\mathrm{N}$ of Valid Cases & 500 & & \\
\hline
\end{tabular}

Table 4.32Symmetric Measures

\begin{tabular}{|c|c|c|c|}
\hline \multicolumn{4}{|l|}{ Symmetric Measures } \\
\hline & & Value & Approx. Sig. \\
\hline Nominal by Nominal & Contingency Coefficient & .295 & .000 \\
\hline \multicolumn{2}{|l|}{$\mathrm{N}$ of Valid Cases } & 500 & \\
\hline \multicolumn{4}{|c|}{ a. Not assuming the null hypothesis. } \\
\hline
\end{tabular}

Interpretation: From the table we find out that asymptotic significance for Pearson Chi Square comes out to be 0.000 (less than 0.05 ) so we reject null hypothesis at $5 \%$ level of significance. Hence it can be concluded that two variables are associated.

Table 4.33Crosstab: I am highly organized in my work.

\begin{tabular}{|c|c|c|c|c|c|c|c|c|}
\hline \multicolumn{9}{|l|}{ Crosstab } \\
\hline & & & I am highly org & nized in & vork. & & & Total \\
\hline & & & Strongly agree & Agree & Neutral & Disagree & Strongly disagree & \\
\hline \multirow{10}{*}{$\begin{array}{l}\text { I } \quad \text { am } \\
\text { emotionally } \\
\text { intelligent. }\end{array}$} & \multirow{2}{*}{ Strongly agree } & Count & 11 & 54 & 45 & 20 & 4 & 134 \\
\hline & & $\%$ of Total & $2.2 \%$ & $10.8 \%$ & $9.0 \%$ & $4.0 \%$ & $0.8 \%$ & $26.8 \%$ \\
\hline & \multirow{2}{*}{ Agree } & Count & 29 & 95 & 50 & 14 & 10 & 198 \\
\hline & & $\%$ of Total & $5.8 \%$ & $19.0 \%$ & $10.0 \%$ & $2.8 \%$ & $2.0 \%$ & $39.6 \%$ \\
\hline & \multirow{2}{*}{ Neutral } & Count & 7 & 55 & 43 & 26 & 11 & 142 \\
\hline & & $\%$ of Total & $1.4 \%$ & $11.0 \%$ & $8.6 \%$ & $5.2 \%$ & $2.2 \%$ & $28.4 \%$ \\
\hline & \multirow{2}{*}{ Disagree } & Count & 0 & 10 & 10 & 0 & 0 & 20 \\
\hline & & $\%$ of Total & $0.0 \%$ & $2.0 \%$ & $2.0 \%$ & $0.0 \%$ & $0.0 \%$ & $4.0 \%$ \\
\hline & \multirow{2}{*}{$\begin{array}{l}\text { Strongly } \\
\text { disagree }\end{array}$} & Count & 0 & 0 & 6 & 0 & 0 & 6 \\
\hline & & $\%$ of Total & $0.0 \%$ & $0.0 \%$ & $1.2 \%$ & $0.0 \%$ & $0.0 \%$ & $1.2 \%$ \\
\hline \multirow{2}{*}{\multicolumn{2}{|c|}{ Total }} & Count & 47 & 214 & 154 & 60 & 25 & 500 \\
\hline & & $\%$ of Total & $9.4 \%$ & $42.8 \%$ & $30.8 \%$ & $12.0 \%$ & $5.0 \%$ & $100.0 \%$ \\
\hline
\end{tabular}

Interpretation: from the above crosstab, it can said that out of total 500 respondents (Software Professionals), $9.4 \%$ respondents strongly agreed, $42.8 \%$ respondents agreed, $30.8 \%$ respondents were neutral, $12 \%$ respondents disagreed and 5\% respondents strongly disagreed that I am highly organised in my work. 


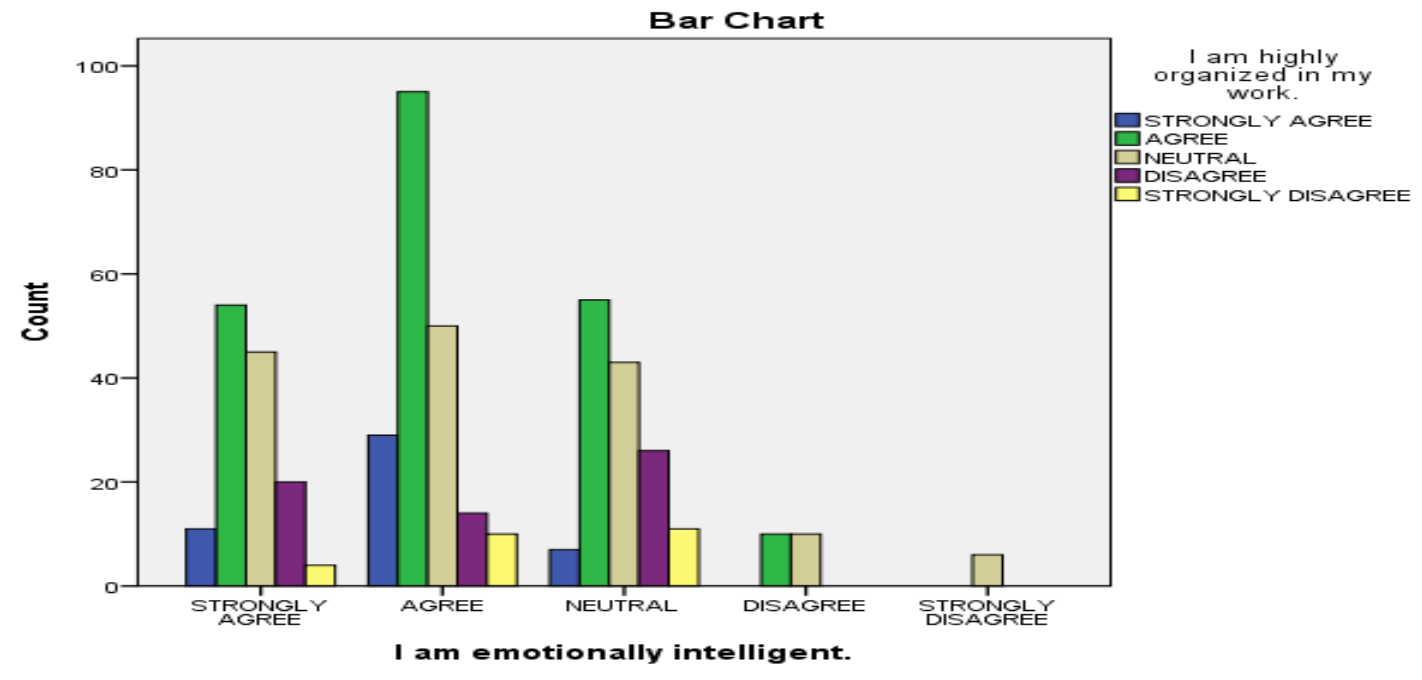

From the above results it can be seen that there was an association between all the independent variables of Personal Competence and the dependent variable-Emotional Intelligence.

Hence, it can be said that our Alternate Hypothesis (H1) -2 is accepted and Null Hypothesis (H0) -2 is rejected and Research Objective- 2 is fulfilled.

4.4. CHI Square Analysis:Analysis of the Association between Emotional Intelligence and Social Competence

4.4.1. Analysis: Social Competence: Analysis of the relationship between emotional intelligence andI have a clear understanding about others' strengths and weaknessesof the software professional in India.

H0: The two factors are independent.

H1: The two factors are not independent (associated).

Tool Used: Chi Square Test (Analyze $\rightarrow$ Descriptive Statistics $\rightarrow$ Crosstabs)

Table 4.34Chi-Square Tests

\begin{tabular}{|l|l|l|l|}
\hline Chi-Square Tests & Value & df & Asymp. Sig. (2-sided) \\
\hline & $89.957^{\mathrm{a}}$ & 16 & .000 \\
\hline Pearson Chi-Square & 93.141 & 16 & .000 \\
\hline Likelihood Ratio & 15.237 & 1 & .000 \\
\hline Linear-by-Linear Association & 500 & & \\
\hline N of Valid Cases & \multicolumn{2}{l}{} \\
\hline a. 10 cells (40.0\%) have expected count less than 5. The minimum expected count is .16. \\
\hline
\end{tabular}

Table 4.35Symmetric Measures

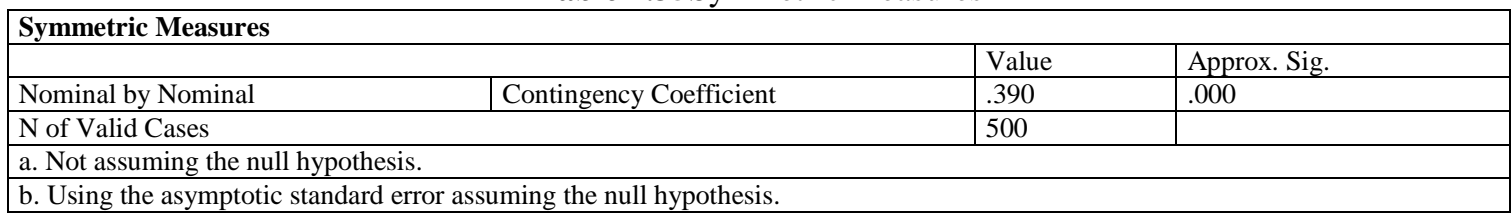

Interpretation: From the table we find out that asymptotic significance for Pearson Chi Square comes out to be 0.000 (less than 0.05 ) so we reject null hypothesis at $5 \%$ level of significance. Hence it can be concluded that two variables are associated.

Table 4.36Crosstab: I have a clear understanding about others' strengths and weaknesses.

\begin{tabular}{|c|c|c|c|c|c|c|c|c|}
\hline \multicolumn{9}{|l|}{ Crosstab } \\
\hline & & & \multicolumn{5}{|c|}{ I have a clear understanding about others' strengths and weaknesses. } & \multirow[t]{2}{*}{ Total } \\
\hline & & & $\begin{array}{l}\text { Strongly } \\
\text { agree }\end{array}$ & Agree & Neutral & Disagree & $\begin{array}{l}\text { Strongly } \\
\text { disagree }\end{array}$ & \\
\hline \multirow{4}{*}{$\begin{array}{l}\text { I am } \\
\text { emotionally } \\
\text { intelligent. }\end{array}$} & \multirow{2}{*}{$\begin{array}{l}\text { Strongly } \\
\text { agree }\end{array}$} & Count & 12 & 84 & 34 & 0 & 4 & 134 \\
\hline & & $\%$ of Total & $2.4 \%$ & $16.8 \%$ & $6.8 \%$ & $0.0 \%$ & $0.8 \%$ & $26.8 \%$ \\
\hline & \multirow{2}{*}{ Agree } & Count & 29 & 78 & 76 & 12 & 3 & 198 \\
\hline & & $\%$ of Total & $5.8 \%$ & $15.6 \%$ & $15.2 \%$ & $2.4 \%$ & $0.6 \%$ & $39.6 \%$ \\
\hline
\end{tabular}


Topic: A study of the association between self-awareness, personal \& social competence with the

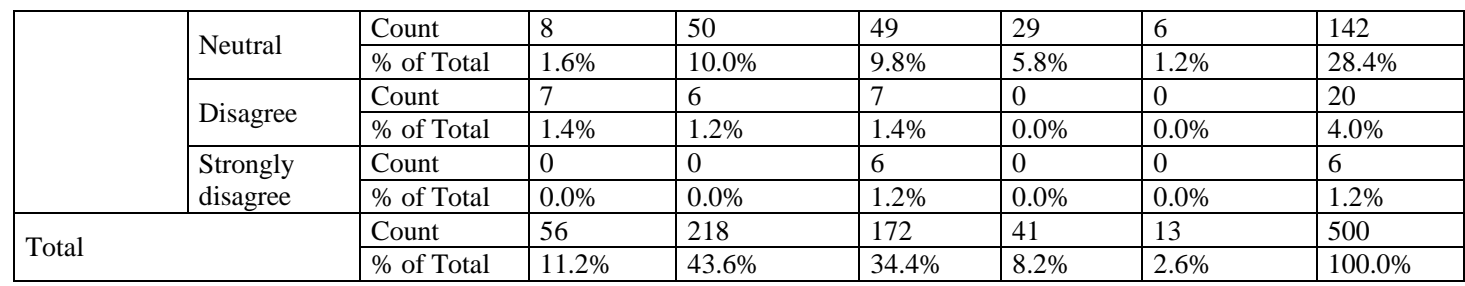

Interpretation: from the above crosstab, it can said that out of total 500 respondents (Software Professionals), $11.2 \%$ respondents strongly agreed, $43.6 \%$ respondents agreed, $34.4 \%$ respondents were neutral, $8.2 \%$ respondents disagreed and $2.6 \%$ respondents strongly disagreed that $\mathbf{I}$ have a clear understanding about others' strengths and weaknesses.

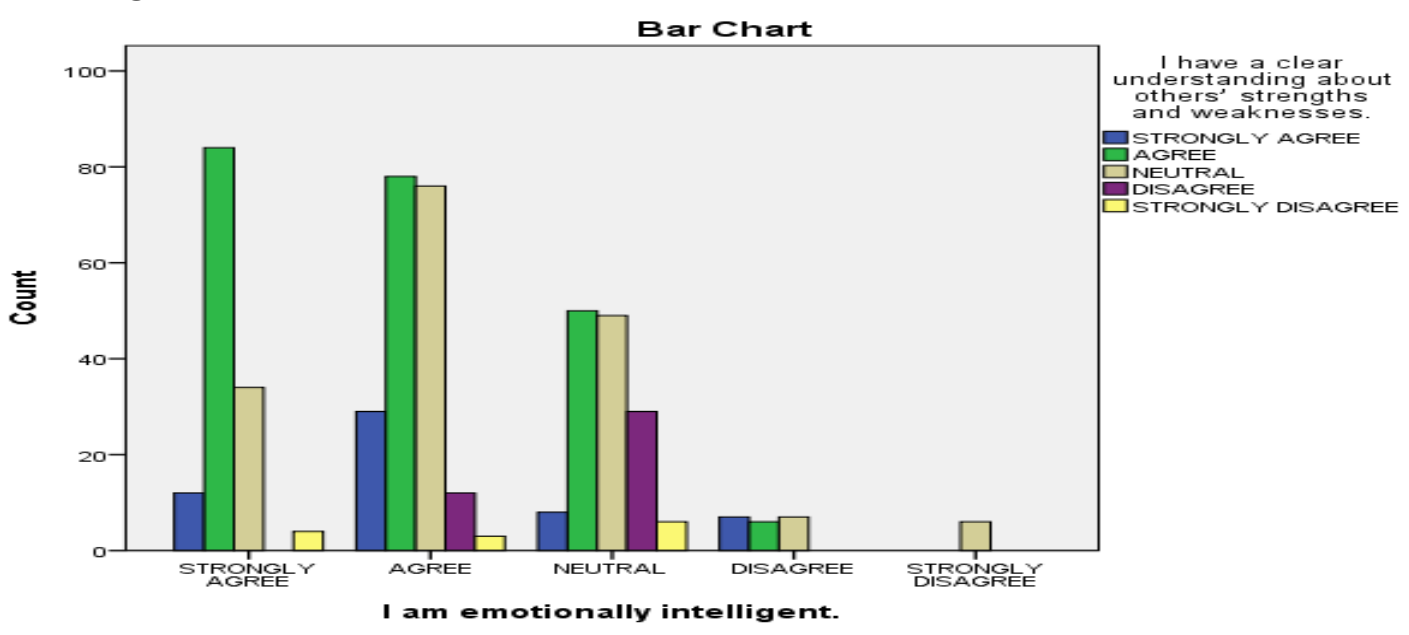

4.4.2. Analysis: Analysis of the relationship between emotional intelligence andI know what motivate and satisfy clientsof the software professional in India.

H0: The two factors are independent.

H1: The two factors are not independent (associated).

Tool Used: Chi Square Test (Analyze $\rightarrow$ Descriptive Statistics $\rightarrow$ Crosstabs)

Table 4.37Chi-Square Tests

\begin{tabular}{|l|l|l|l|}
\hline Chi-Square Tests & df & Asymp. Sig. (2-sided) \\
\hline & Value & df & $.883^{\mathrm{a}}$ \\
\hline Pearson Chi-Square & 36.798 & 16 & .001 \\
\hline Likelihood Ratio & 1.830 & 16 & .002 \\
\hline Linear-by-Linear Association & 500 & 1 & .176 \\
\hline N of Valid Cases & & \\
\hline a. 8 cells (32.0\%) have expected count less than 5. The minimum expected count is .24. \\
\hline
\end{tabular}

Table 4.38 Symmetric Measures

\begin{tabular}{|c|c|c|c|}
\hline \multicolumn{4}{|l|}{ Symmetric Measures } \\
\hline & & Value & Approx. Sig. \\
\hline Nominal by Nominal & Contingency Coefficient & .272 & .001 \\
\hline \multicolumn{2}{|l|}{$\mathrm{N}$ of Valid Cases } & 500 & \\
\hline
\end{tabular}

Interpretation: From the table we find out that asymptotic significance for Pearson Chi Square comes out to be 0.000 (less than 0.05 ) so we reject null hypothesis at $5 \%$ level of significance. Hence it can be concluded that two variables are associated.

Table 4.39Crosstab: I know what motivate and satisfy clients

\begin{tabular}{|c|c|c|c|c|c|c|c|c|}
\hline \multicolumn{9}{|l|}{ Crosstab } \\
\hline & & & \multicolumn{5}{|c|}{ I know what motivate and satisfy clients. } & \multirow[t]{2}{*}{ Total } \\
\hline & & & Strongly agree & Agree & Neutral & Disagree & Strongly disagree & \\
\hline \multirow{2}{*}{ I $\quad$ am } & \multirow{2}{*}{ Strongly agree } & Count & 25 & 54 & 44 & 7 & 4 & 134 \\
\hline & & $\%$ of Total & $5.0 \%$ & $10.8 \%$ & $8.8 \%$ & $1.4 \%$ & $0.8 \%$ & $26.8 \%$ \\
\hline
\end{tabular}


Topic: A study of the association between self-awareness, personal \& social competence with the

\begin{tabular}{|c|c|c|c|c|c|c|c|c|}
\hline \multirow[t]{8}{*}{ intelligent. } & \multirow{2}{*}{ Agree } & Count & 20 & 97 & 49 & 19 & 13 & 198 \\
\hline & & $\%$ of Total & $4.0 \%$ & $19.4 \%$ & $9.8 \%$ & $3.8 \%$ & $2.6 \%$ & $39.6 \%$ \\
\hline & \multirow{2}{*}{ Neutral } & Count & 16 & 55 & 57 & 11 & 3 & 142 \\
\hline & & $\%$ of Total & $3.2 \%$ & $11.0 \%$ & $11.4 \%$ & $2.2 \%$ & $0.6 \%$ & $28.4 \%$ \\
\hline & \multirow{2}{*}{ Disagree } & Count & 3 & 11 & 3 & 3 & 0 & 20 \\
\hline & & $\%$ of Total & $0.6 \%$ & $2.2 \%$ & $0.6 \%$ & $0.6 \%$ & $0.0 \%$ & $4.0 \%$ \\
\hline & \multirow{2}{*}{$\begin{array}{l}\text { Strongly } \\
\text { disagree }\end{array}$} & Count & 0 & 3 & 0 & 3 & 0 & 6 \\
\hline & & $\%$ of Total & $0.0 \%$ & $0.6 \%$ & $0.0 \%$ & $0.6 \%$ & $0.0 \%$ & $1.2 \%$ \\
\hline \multirow{2}{*}{\multicolumn{2}{|c|}{ Total }} & Count & 64 & 220 & 153 & 43 & 20 & 500 \\
\hline & & $\%$ of Total & $12.8 \%$ & $44.0 \%$ & $30.6 \%$ & $8.6 \%$ & $4.0 \%$ & $100.0 \%$ \\
\hline
\end{tabular}

Interpretation: From the above crosstab, it can said that out of total 500 respondents (Software Professionals), $12.8 \%$ respondents strongly agreed, $44 \%$ respondents agreed, $30.6 \%$ respondents were neutral, $8.6 \%$ respondents disagreed and $4.0 \%$ respondents strongly disagreed that I know what motivate and satisfy clients.

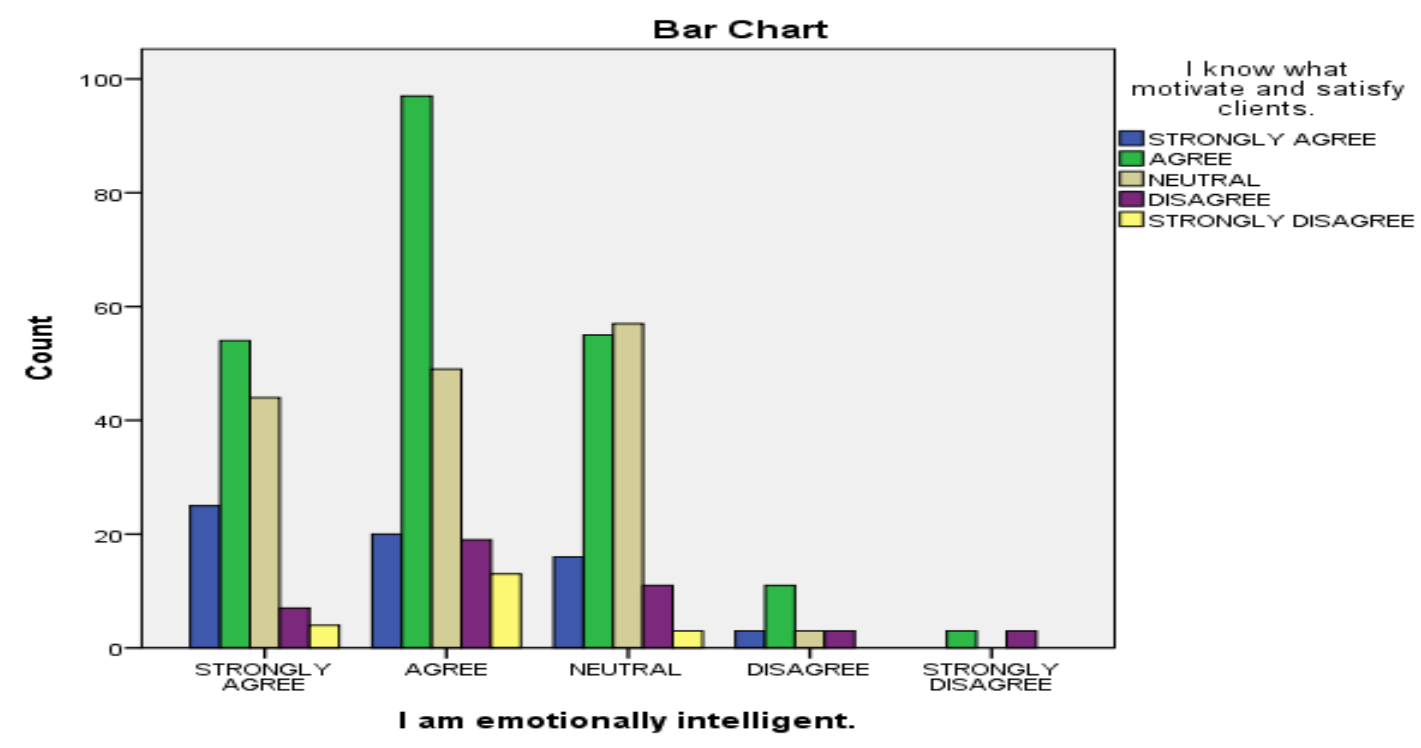

4.4.3 Analysis: Analysis of the relationship between emotional intelligence andI try to build personal rapport and long term relationship with others and the software professional in India.

H0: The two factors are independent.

H1: The two factors are not independent (associated).

Tool Used: Chi Square Test (Analyze $\rightarrow$ Descriptive Statistics $\rightarrow$ Crosstabs)

Table 4.40Chi-Square Tests

\begin{tabular}{|l|l|l|l|}
\hline \multicolumn{3}{|l|}{ Chi-Square Tests } & Asymp. Sig. (2-sided) \\
\hline & Value & df & .000 \\
\hline Pearson Chi-Square & $75.437^{\mathrm{a}}$ & 16 & .000 \\
\hline Likelihood Ratio & 55.491 & 16 & .000 \\
\hline Linear-by-Linear Association & 15.315 & 1 & \\
\hline N of Valid Cases & 500 & & \\
\hline a. 10 cells (40.0\%) have expected count less than 5. The minimum expected count is .22. \\
\hline
\end{tabular}

Table 4.41Symmetric Measures

\begin{tabular}{|c|c|c|c|}
\hline \multicolumn{4}{|l|}{ Symmetric Measures } \\
\hline & & Value & Approx. Sig. \\
\hline Nominal by Nominal & Contingency Coefficient & .362 & .000 \\
\hline $\mathrm{N}$ of Valid Cases & & 500 & \\
\hline
\end{tabular}

Interpretation: From the table we find out that asymptotic significance for Pearson Chi Square comes out to be 0.000 (less than 0.05 ) so we reject null hypothesis at $5 \%$ level of significance. Hence it can be concluded that two variables are associated.

Table 4.42Crosstab: I try to build personal rapport and long term relationship with others

\begin{tabular}{|l|c|l|}
\hline Crosstab & \multicolumn{3}{l|}{} \\
\hline & I try to build personal rapport and long term relationship with others. & Total \\
\hline DOI: $10.9790 / 487 X-1907017494$ & www.iosrjournals.org & $90 \mid$ Page
\end{tabular}


Topic: A study of the association between self-awareness, personal \& social competence with the

\begin{tabular}{|c|c|c|c|c|c|c|c|c|}
\hline & & & $\begin{array}{l}\text { Strongly } \\
\text { agree }\end{array}$ & Agree & Neutral & Disagree & $\begin{array}{l}\text { Strongly } \\
\text { disagree }\end{array}$ & \\
\hline \multirow{8}{*}{$\begin{array}{l}\text { I am } \\
\text { emotionally } \\
\text { intelligent. }\end{array}$} & \multirow{2}{*}{ Strongly agree } & Count & 34 & 68 & 24 & 4 & 4 & 134 \\
\hline & & $\%$ of Total & $6.8 \%$ & $13.6 \%$ & $4.8 \%$ & $0.8 \%$ & $0.8 \%$ & $26.8 \%$ \\
\hline & Agree & $\%$ of Total & $7.6 \%$ & $17.6 \%$ & $11.4 \%$ & $1.6 \%$ & $1.4 \%$ & $39.6 \%$ \\
\hline & \multirow{2}{*}{ Neutral } & Count & 16 & 54 & 62 & 6 & 4 & 142 \\
\hline & & $\%$ of Total & $3.2 \%$ & $10.8 \%$ & $12.4 \%$ & $1.2 \%$ & $0.8 \%$ & $28.4 \%$ \\
\hline & Disagree & $\%$ of Total & $1.4 \%$ & $0.6 \%$ & $2.0 \%$ & $0.0 \%$ & $0.0 \%$ & $4.0 \%$ \\
\hline & \multirow{2}{*}{$\begin{array}{l}\text { Strongly } \\
\text { disagree }\end{array}$} & Count & 0 & 3 & 0 & 0 & 3 & 6 \\
\hline & & $\%$ of Total & $0.0 \%$ & $0.6 \%$ & $0.0 \%$ & $0.0 \%$ & $0.6 \%$ & $1.2 \%$ \\
\hline \multirow{2}{*}{\multicolumn{2}{|c|}{ Total }} & Count & 95 & 216 & 153 & 18 & 18 & 500 \\
\hline & & $\%$ of Total & $19.0 \%$ & $43.2 \%$ & $30.6 \%$ & $3.6 \%$ & $3.6 \%$ & $100.0 \%$ \\
\hline
\end{tabular}

Interpretation: from the above crosstab, it can said that out of total 500 respondents (Software Professionals), $19 \%$ respondents strongly agreed, $43.2 \%$ respondents agreed, $30.6 \%$ respondents were neutral, $3.6 \%$ respondents disagreed and 3.6\% respondents strongly disagreed that I try to build personal rapport and long term relationship with others.

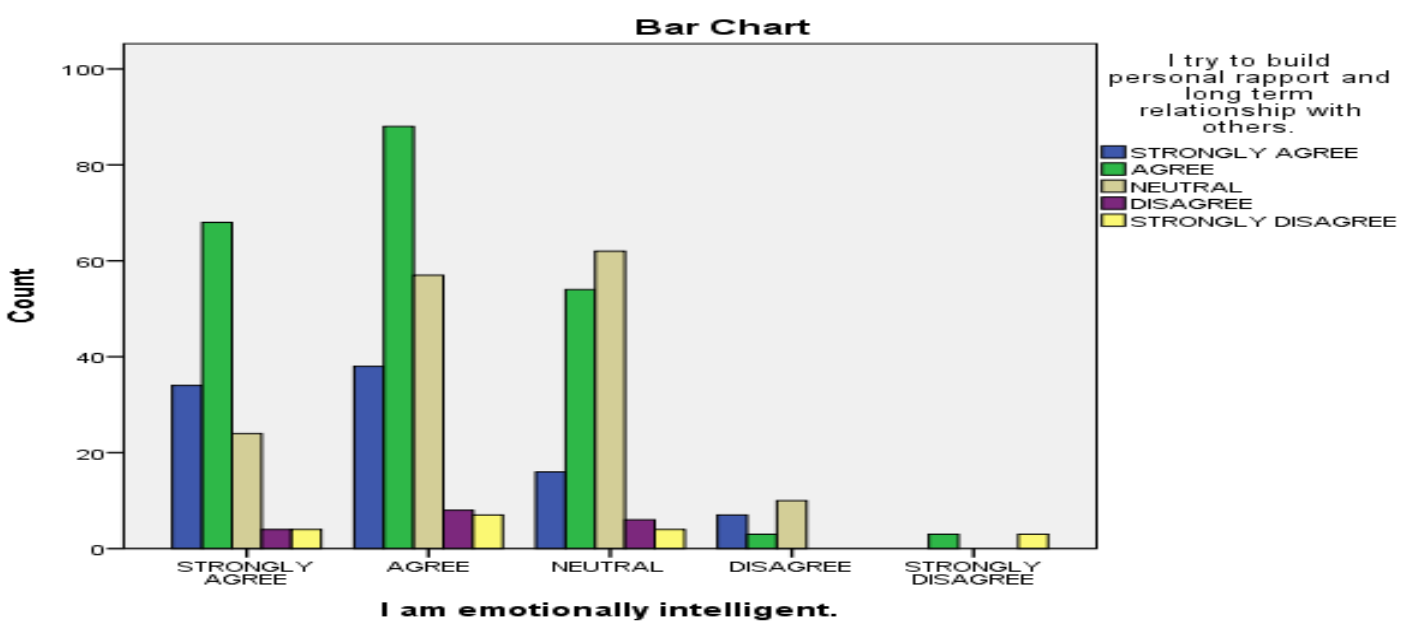

4.4.4 Analysis: Analysis of the relationship between emotional intelligence andI have a special ability to take along people with different points of view of the software professional in India.

H0: The two factors are independent.

H1: The two factors are not independent (associated).

Tool Used: Chi Square Test (Analyze $\rightarrow$ Descriptive Statistics $\rightarrow$ Crosstabs)

Table 4.43Chi-Square Tests

\begin{tabular}{|l|l|l|l|}
\hline Chi-Square Tests & Value & df & Asymp. Sig. (2-sided) \\
\hline & $143.119^{\mathrm{a}}$ & 16 & .000 \\
\hline Pearson Chi-Square & 86.335 & 16 & .000 \\
\hline Likelihood Ratio & 2.275 & 1 & .131 \\
\hline Linear-by-Linear Association & 500 & & \\
\hline N of Valid Cases & 500 . The minimum expected count is .11. \\
\hline a. 11 cells (44.0\%) have expected count less than 5. The
\end{tabular}

Table 4.44Symmetric Measures

\begin{tabular}{|c|c|c|c|}
\hline \multicolumn{4}{|l|}{ Symmetric Measures } \\
\hline & & Value & Approx. Sig \\
\hline Nominal by Nominal & Contingency Coefficient & .472 & .000 \\
\hline $\mathrm{N}$ of Valid Cases & & 500 & \\
\hline
\end{tabular}

Interpretation: From the table we find out that asymptotic significance for Pearson Chi Square comes out to be 0.000 (less than 0.05 ) so we reject null hypothesis at $5 \%$ level of significance. Hence it can be concluded that two variables are associated.

Table 4.45Crosstab: I have a special ability to take along people with different points of view

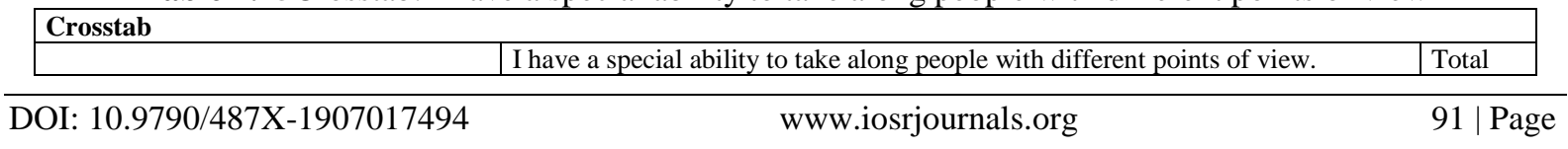


Topic: A study of the association between self-awareness, personal \& social competence with the

\begin{tabular}{|c|c|c|c|c|c|c|c|c|}
\hline & & & Strongly agree & Agree & Neutral & Disagree & Strongly disagree & \\
\hline \multirow{7}{*}{$\begin{array}{l}\text { I am } \\
\text { emotionally } \\
\text { intelligent. }\end{array}$} & $\begin{array}{l}\text { Strongly } \\
\text { agree }\end{array}$ & Count & 42 & 42 & 28 & 22 & 0 & 134 \\
\hline & Agree & Count & 22 & 103 & 67 & 3 & 3 & 198 \\
\hline & \multirow{2}{*}{ Neutral } & Count & 24 & 63 & 41 & 11 & 3 & 142 \\
\hline & & $\%$ of Total & $4.8 \%$ & $12.6 \%$ & $8.2 \%$ & $2.2 \%$ & $0.6 \%$ & $28.4 \%$ \\
\hline & Disagree & Count & 3 & 13 & 4 & 0 & 0 & 20 \\
\hline & \multirow{2}{*}{$\begin{array}{l}\text { Strongly } \\
\text { disagree }\end{array}$} & Count & 0 & 3 & 0 & 0 & 3 & 6 \\
\hline & & $\%$ of Total & $0.0 \%$ & $0.6 \%$ & $0.0 \%$ & $0.0 \%$ & $0.6 \%$ & $1.2 \%$ \\
\hline \multirow{2}{*}{\multicolumn{2}{|c|}{ Total }} & Count & 91 & 224 & 140 & 36 & 9 & 500 \\
\hline & & $\%$ of Total & $18.2 \%$ & $44.8 \%$ & $28.0 \%$ & $7.2 \%$ & $1.8 \%$ & $100.0 \%$ \\
\hline
\end{tabular}

Interpretation: from the above crosstab, it can said that out of total 500 respondents (Software Professionals), $18.2 \%$ respondents strongly agreed, $44.8 \%$ respondents agreed, $28 \%$ respondents were neutral, $7.2 \%$ respondents disagreed and $1.8 \%$ respondents strongly disagreed that $\mathbf{I}$ have a special ability to take along people with different points of view.

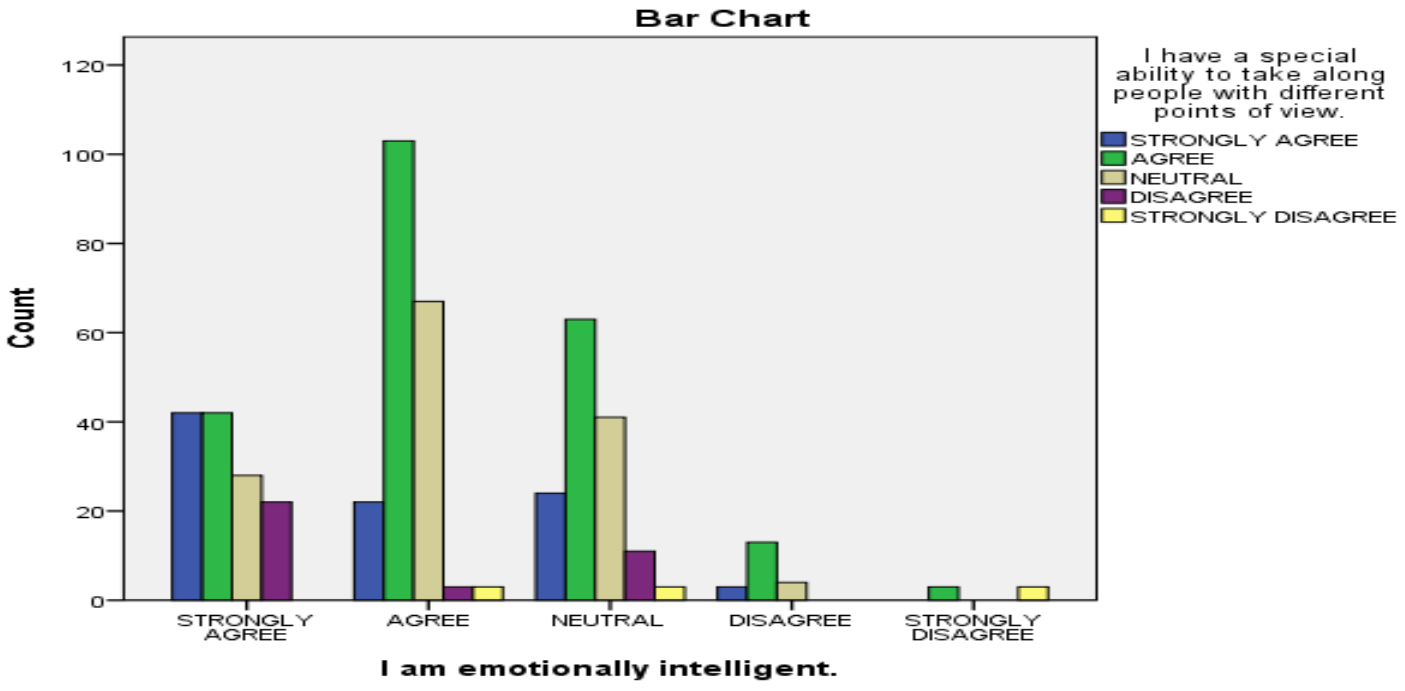

From the above results it can be seen that there was an association between all the independent variables of Social Competence and the dependent variable-Emotional Intelligence.Hence, it can be said that our Alternate Hypothesis (H1)-3 is accepted and Null Hypothesis (H0) -3 is rejected and Research Objective-3 is fulfilled.

\section{Conclusion, Discussion and Practical Implications}

Service businesses especially IT industry has to face a challenge of great operational variability. Service delivery process is complex and also involves human element that is software professional have to deal the clients directly as clients participate directly in on-going operations. It has become mandatory for any software professional to be not only technically skilled but also possess behavioural competence. As selfawareness, personal and social competencies help software professional to be emotionally intelligent, and it also leads to the enhanced and value-added performance of any individual as well as of organisational performance. Such dynamics of service firms makes it necessary for employees to be capable of handling the customers by accommodating the wide variety of requests made to the company. For service firms, the only strategy to retain their intellectual capital is to hire and keep good employees (Mcbride, Maitland, 2002) who can serve the varying demands of customers. The above discussion highlights the importance of software professionals' emotional intelligence to understand, empathise and efficiently deal with job-related problems, to perform efficiently too which is necessary to succeed in the dynamic work environment.On the other hand, employers require their software professionals to be emotionally intelligent to serve clients in a best possible manner and to create as well as maintain healthy work environment. They need to assess software professionals' EI to facilitate their recruitment, selection, promotion and retention.In the present study, the association between selfawareness, personal competence and social competence and emotional intelligence of software professionals working in IT industry had been checked. The result of the study proves that above mentioned competencies are associated with emotional intelligence of software professionals. The result is evident and in compliance with the expectations of researchers as well as in agreement with the previous researches.

Self-Awareness 
Following independent variables related to self-awareness competencies were analysed for their association with EI of software professionals and it was found that all the variables are associated with EI of software professionals.

- I am conscious of my needs and wants in life.

- I have a clear understanding about my own strengths and weakness.

- I am now aware of what I think and feel and how I act in a situation.

- I think a lot before I act.

- I consider all the possibilities before making a decision.

- I know what motivates and satisfies me.

Personal Competence

Following independent variables related to personal competence were analysed for their association with EI of software professionals and it was found that all the variables are associated with EI of software professionals.

- I have the ability to tackle all problems with analytical approach.

- I build faith through my reliability.

- I take responsibility for my personal performance.

- I am able to maintain the standards of honesty and integrity.

- I am highly organized in my work.

Social Competence

Following independent variables related to social competence were analysed for their association with EI of software professionals and it was found that all the variables are associated with EI of software professionals.

- I have a clear understanding about others' strengths and weaknesses.

- I know what motivate and satisfy clients.

- I try to build personal rapport and long term relationship with others.

- I have a special ability to take along people with different points of view.

Emotional intelligence is essential not only for the overall development of software professionals but also for the complete utilisation of their technical skills by any organisation. They will have to realise that they have to satisfy the clients and deliver the services as efficiently as possible. They must be able to empathise with their clients so that they can spot and prevent where personality clashes may impact on work performance.

\section{References and Bibliography}

[1] Abraham, J. (2004). The quest for the spiritual neuron (2nd ed.). Bangalore: Dharmaram Publications.

[2] Adeyemo, D.A. (2007) Moderating influence of emotional intelligence on the link between academic self-efficacy and achievement of university students, Psychology and Developing Socities, 19 (2):199-213.

[3] Allspach, J. R., \&Breining, K. (2005) Gender differences and trends over time for the SAT reasoning test. Barchard, K. A., \&Hakstian, R. A. (2004). The nature and measurement of emotional intelligence abilities: Basic dimensions and their relationships with other cognitive ability and personality variables. Educational \& Psychological Measurement, 64, 437-462. Wong, C.S., Kenneth S. L. (2002). The Effects Of Leader And Follower Emotional Intelligence On Performance And Attitude: An Exploratory Study. The Leadership Quarterly, 13, 243-274.

[4] Birks, Y. F., \& Watt, I. S. (2007). Emotional intelligence and patient-centred care. Journal of the Royal Society of Medicine, 100(8), 368-374.

[5] Boyatzis,R.E.,andRatti,F.(2009)."Emotional,SocialandCognitiveIntelligence Competencies Distinguishing Effective Italian Managers andLeaders in a Private Companyand Cooperatives", Journal of Management Development, Vol 28 (9), $821-838$.

[6] Bradberry, T. \& Greaves, J. (2003). Emotional intelligence quickbook: Everything you need to know, San Diego, CA: Talent Smart Inc.

[7] Carmeli, A. (2003). "The Relationship betweenEmotionalIntelligence Attitudes,BehaviorandOutcomes",JournalofManagerialPsychology,Vol 18, pp 788-813.

[8] Carmeli, A. (2003). The relationship between emotional intelligence and work attitudes, behavior and outcomes. Journal of managerial psychology, 18,788-813.

[9] Cherniss, \&Goleman, D. (2000). An EI-based theory of performance. In D. Goleman (Eds.), The Emotionally Intelligent Workplace. San Francisco: Jossey-Bass.

[10] Cherniss, C., Goleman, D., Emmerling, R., Cowan, K \& Adler, M. (1998). Bringing Emotional Intelligence to the Workplace. A Technical Report Issued by the Consortium for Research on Emotional Intelligence in Organizations. Available http://www.eiconsortium.org

[11] Feist, G. J., \& Barron, F. (1996, June). Emotional intelligence and academic intelligence in career and life success. Paper presented at the Annual Convention of the American Psychological Society, San Francisco, CA.

[12] Feist, G. J., \& Barron, F. (1996, June). Emotional intelligence and academic intelligence in career and life success. Paper presented at the Annual Convention of the American Psychological Society, San Francisco, CA

[13] Gardner, H. (1983). Frames of mind: The theory of multiple intelligences. New York: Basic Books.

[14] Gardner, H. (1995). Cracking open the IQbox. In S. Fraser (Ed.), The bell curve wars (pp.23-35). New York: Basic Books.

[15] Goleman, D. (1995). Emotional Intelligence. New York: Bantam Books.

[16] Goleman, D. (1995). Emotional intelligence: Why it can matter more than IQ. New York, NY: Bantam.

[17] Goleman, D. (1999). Working with Emotional Intelligence. New York: Bantam Books.

[18] Goleman, D. (2001). Primal Leadership: The Hidden Driver of Great Performance. Harvard Business Software company Press.

[19] Goleman, D., Boyatzis, R., \& McKee, R. (2002). Primal leadership: Realizing the power of emotional intelligence. Boston, MA: Harvard Business School Press.

[20] Mcbride, P. \&Maitland, S (2002). The EI advantage. Putting Emotional Intelligence into practice. UK: McGraw Hill International. 
[21] Mcbride, P. \& Maitland, S. (2002) The EI advantage. Putting Emotional Intelligence into practice. UK: McGraw Hill International.

[22] Salovey, P. and Mayer, J.D. (1990). Emotional Intelligence. Imagination, Cognition and Personality. 9, 185-211Goleman, D., McKee, A., \&Boyayzis, R. (2006). Primal leadership: Realizing the power of emotional intelligence. Nursing News, 30(3), 24-24.

[23] Salovey, P., Bedell, B. T., Detweiller, J. B., \& Mayer, J. D. (2000). Coping intelligently: Emotional intelligence and the coping process. In C. R. Snyder (Ed.), Coping: The psychology of what works (pp. 141-164). New York: Oxford University Press.

[24] Salovey, P., Mayer, J. D., Goldman, S. L., Turvey, C., \&Palfai, T. P. (1995). Emotional attention, clarity, and repair: Exploring emotional intelligence using the trait meta-mood scale. In J. W. Pennebaker (Ed.), Emotion, disclosure, \& health (pp. 125-154). Washington, DC: American Psychological Association.

[25] Salovey, P., Stroud, L. R., Woolery, A., \&Epel, E. S. (2002). Perceived emotional intelligence, stress reactivity, and symptom reports: Further explorations using the trait meta-mood scale. Psychology \& Health, 17, 611-627.

[26] Sternberg, R. J. (1989). The triarchic mind: A new theory of human intelligence. New York: Penguin Books.

[27] Sternberg, R. J. (1994). Commentary: Reforming school reform: Comments on "multiple intelligences: The theory in practice.". Teachers College Record, 95(4), 561-69.

[28] Sternberg, R. J. (1997). Thinking styles.New York: Cambridge University Press.

[29] Sternberg, R. J. (2000). Handbook of intelligence Cambridge ; New York : Cambridge University Press, 2000

[30] Thorndike,E.L.(1920).Intelligenceanditsuse.Harper'sMagazine, 140,227-235.

[31] Travis Bradberry, www.forbes.com/sites/travisbradberry/2014/01/09/emotional intelligence/)

[32] Wong, C. S., Wong, P. M., and Peng, K. Z. (2010). "Effect of Middle-Level Leader and Software professional Emotional Intelligence on Software company Software professionals' Job Satisfaction", Educational Management Administration and Leadership, Vol 38 (1), pp 59-70. 